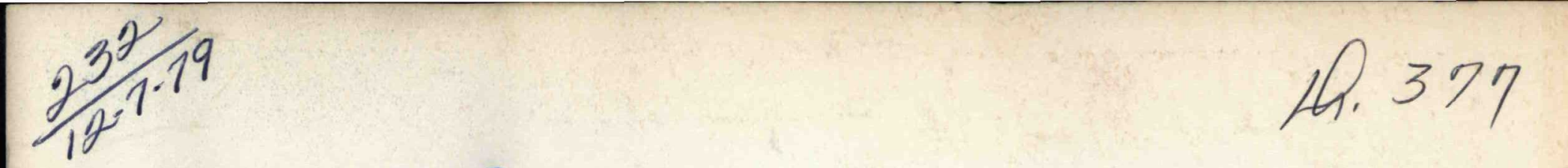

\title{
Analysis of the 1957-58 Soviet Nuclear Accident
} UNION
J. R. Trabalka
L. D. Eyman
S. I. Auerbach

ENVIRONMENTAL SCIENCES DIVISION

Publication No. 1445

\section{MASTER}

OPERATED BY

UNION CARBIDE CORPORATION FOR THE UNITED STATES DEPARTMENT OF ENERGY

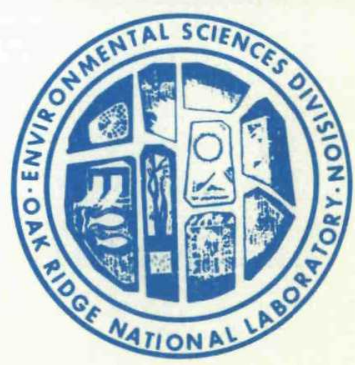


Printed in the United States of America. Available from National Technical Information Service

U.S. Department of Commerce

5285 Port Royal Road, Springfield, Virginia 22161 NTIS price codes-Printed Copy: A05 Microfiche A01

This report was prepared as an account of work sponsored by an agency of the United States Government. Neither the United States nor any agency thereof, nor any of their employees, makes any warranty, expressed or implied, or assumes any legal liability or responsibility for any third party's use or the results of such use of any information, apparatus, product or process disclosed in this report, or represents that its use by such third party would not infringe privately owned rights. 


\section{ORNL-5613 \\ Distribution Category - UC-11}

Contract No. W-7405-eng-26

ANALYSIS OF THE 1957-58 SOVIET NUCLEAR ACCIDENT

J. R. Trabalka, L. D. Eyman, and S. I. Auerbach

ENVIRONMENTAL SCIENCES DIVISION

Publication No. 1445

Date Published: December 1979

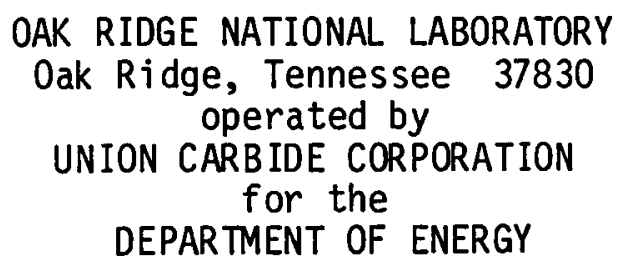




\section{ACKNOWLEDGMENTS}

We thank Z. A. Medvedev for focusing our attention on this challenging and important subject; A. T. Gresky, S. J. Rimshaw, and E. G. Struxness for technical advice and assistance in obtaining important reference materials; and the efficient, courteous staff of the Central Research Library, especially E. P. Nunn, 0. H. Russe11, and C. B. Andrews. We also thank other colleagues at Oak Ridge National Laboratory who provided us with constructive criticisms, additional reference material, and enthusiastic encouragement during the preparation of this manuscript, in particular: F. T. Binford, R. E. Blanco, J. O. Blomeke, E. A. Bondietti, R. H. Cooper, N. H. Cutsha11, C. W. Francis, W. F. Harris, S. G. Hildebrand, J. M. Holmes, A. D. Kelmers, L. T. Newman, D. E. Reichle, J. P. Witherspoon, and R. G. Wymer. 
-

.

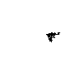


J. R. TRABALKA, L. D. EYMAN, and S. I. AUERBACH. 1979. Analysis of the 1957-58 soviet nuclear accident. ORNL-5613. Oak Ridge National Laboratory, Oak Ridge, Tennessee. $82 \mathrm{pp}$.

The occurrence of a Soviet accident in the winter of 1957-58, involving the atmospheric release of reprocessed fission wastes (cooling time approximately $1-2$ years), appears to have been confirmed, primarily by an analys is of the U.S.S.R. radioecology literature. Due to the high population density in the affected region (Cheliabinsk Province in the highly industrialized Urals Region) and the reported level of ${ }^{90} \mathrm{Sr}$ contamination, the event probably resulted in the evacuation and/or resettlement of the human population from a significant area $\left(100-1000 \mathrm{~km}^{2}\right)$. The resulting contamination zone is estimated to have contained approximately $10^{6} \mathrm{Ci}$ of ${ }^{90} \mathrm{Sr}$ (reference radionuclide): a relatively small fraction of the total may have been dispersed as an aerosol. Although a plausible explanation for the incident exists (i.e., use of now-obsolete waste storage- ${ }^{137} \mathrm{Cs}$ isotope separation techniques), it is not yet possible, based on the limited information presently available, to completely dismiss this phenomenon as a purely historical event. It seems imperative that we have a complete explanation of the causes(s) and consequences of this incident. Soviet experience gained in application of corrective measures would be invaluable to the rest of the world nuclear community. 
-

.

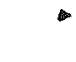


Page

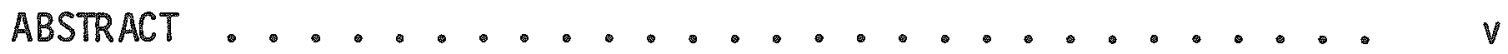

LIST OF TABLES ........................... ix

LIST OF FIGURES ............................. ix

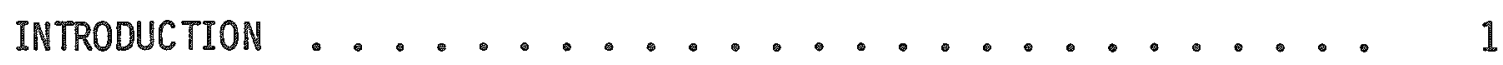

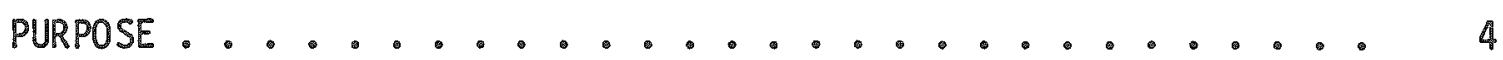

SOVIET RADIOECOLOGY SOURCES ............... 5

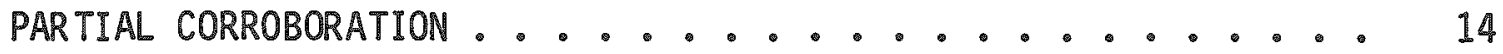

REMEDIAL MEASURES ......................... 16

POTENTIAL CAUSES ............................ 22

NUCLEAR EXPLOSIVES ACC IDENTS ............. 26

PLUTONIUM PRODUCTION ACC IDENTS .............. 27

CESIUM SEPARATION MECHANISMS ............. 34

PROBABLE SOURCE ...................... 37

POTENTIAL DISPERSAL MECHANISMS FOR HIGH-LEVEL WASTES ..... 37

ACC IDENT SCRIPTS .......................... 41

ANOTHER VIEWPOINT ....................... 45

ADDITIONAL SUPPORT FOR HIGH-LEVEL WASTE ACCIDENT $\ldots \ldots . \ldots 48$

SUMMARY AND CONCLUSIONS ............... 49

REFERENCES ........................ 54 
-

. 


\section{LIST OF TABLES}

Table

Page

1 Ratios of individual reactor fission product activities to ${ }^{137} \mathrm{Cs}$ (Ci of F.P.:Ci of $137 \mathrm{Cs}$ for various decay times......................

\section{LIST OF FIGURES}

Figure

1 Geographic region in which a Soviet catastrophe involving nuclear wastes is reported to have occurred ........

2 Reservoir/canal system apparently constructed to reduce hydrologic transport of radioactive materials down the Techa River system . . . . . . . . . . . . . . . 


\section{INTRODUCTION}

Retrospective accounts by former Soviet citizens (primarily by two individuals, 1-6,7) have suggested the presence of an extensive, uninhabited area contaminated by radioactive materials in Cheliabinsk Province (Ural Mountains) of the U.S.S.R. One source reported (L. Tumerman, 7) that he encountered a highly radioactive, restricted area $(20-30 \mathrm{~km}$ 10ng, approximately $100 \mathrm{~km}$ south of the city of Sverdlovsk) during an automobile trip from Cheliabinsk to Sverdlovsk in 1961. Both individuals believed, based on information supplied to them from a variety of sources $(3,7)$, that the contaminated area was created following an explosion in a nuclear waste storage site (associated with plutonium production for military weapons) in the late 1950's. They were told that the accident resulted in significant loss of life (hundreds of people) and required the permanent evacuation of the civilian population from a large area.

Information (extensively edited and unevaluated) released from the United States Central Intelligence Agency (CIA) files to a citizens' group (8) indicated the presence of military nuclear installations (Techa-Reactor, SunguT-Radiological Institute) near the city of Kasli (Fig. 1). These installations were located among many large lakes in the upper Techa River Drainage. The Techa River itself reportedly (8) had been contaminated with radioactivity throughout its course, perhaps to some extent as early as 1954. The CIA documents indicate the occurrence of a nuclear-related incident(s) and subsequent presence of high-level radioactive contamination in this area between 1956-1961, 


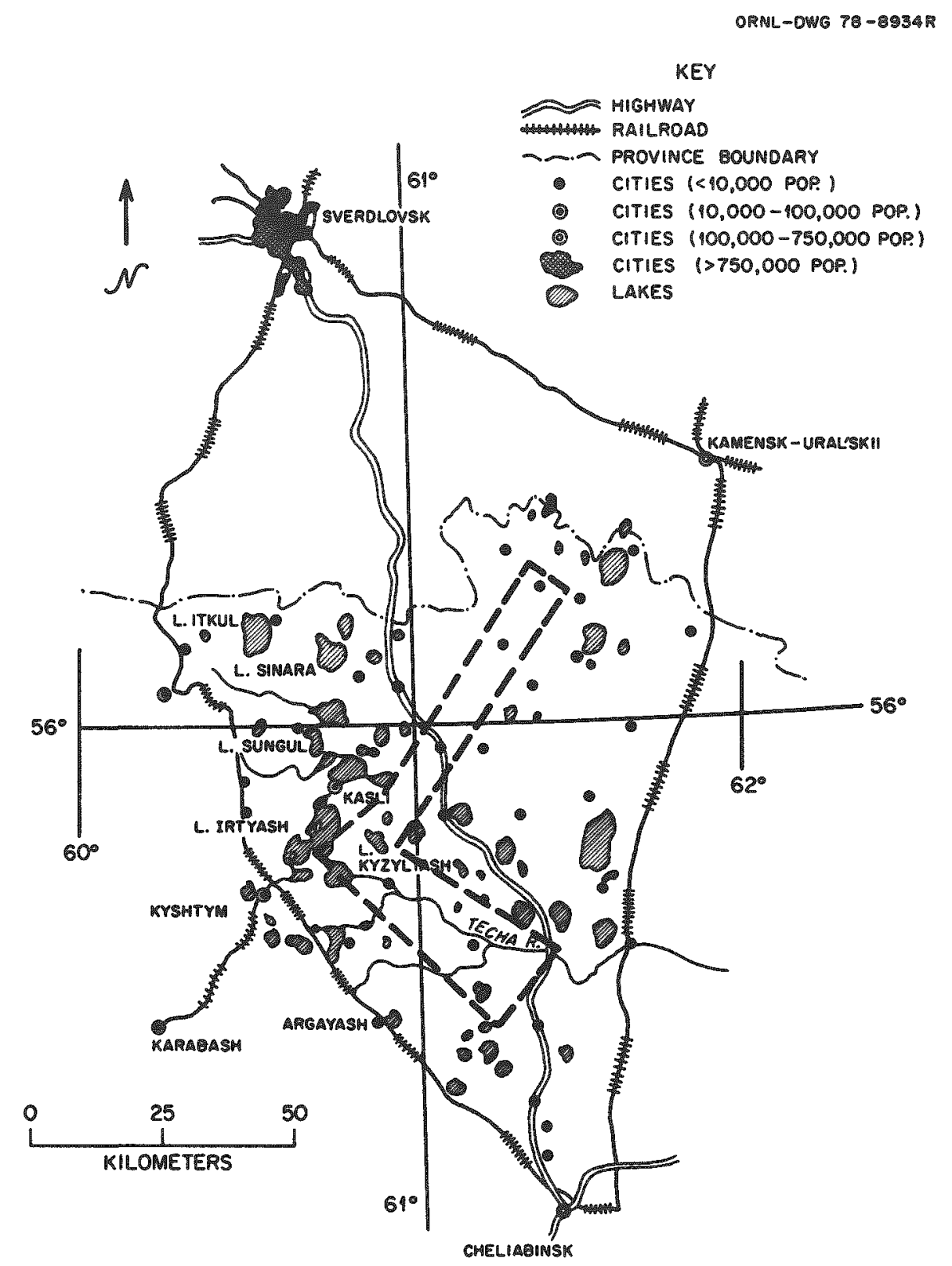

Fig. 1. Geographic region in which a Soviet catastrophe involving nuclear wastes is reported to have occurred. Map is based on pre-accident geographic features. Dashed area indicates zone in which extensive changes in population centers and surface hydrologic features appear after the accident. [See later discussion in Remedial Measures Section (Redrawn from 9)] 
most probably in the winter of 1957-1958. No cause(s) was clearly identified; possibilities suggested (8) were either an accident associated with high-level waste storage or an experimental nuclear weapons test. The scope of the incident, in human terms, was not we 17-defined, but appeared to involve some loss of life (magnitude undetermined), evacuation of the civilian population from a large area, and the appearance of a restricted, radioactive contamination zone east of Kasli.

The CIA documents appear to corroborate at least some aspects of the conclusions drawn by former Soviet citizens. However, any objective observer must also conclude that there are significant inconsistent elements internal to both sets of information $(1,3,8)$. A disturbing feature of both information sets is the notable absence of either first- or second-person accounts of the incident itself or confirmed authoritative information related to its aftermath. We have no reason to doubt either the veracity or sincerity of the reports made by Soviet citizens either to the press or to the CIA, or in magazine accounts $(1,3,4,7,8)$. However, we quickly recognized that we must have additional objective information in order to perform a credible, scientific evaluation of the incident. A critique of the information supplied by former Soviet citizens and the CIA is certainly not the purpose of this paper, but will be reported elsewhere (10).

The first (and most comprehensive) published reports of a Soviet nuclear accident are attributable to $Z$. A. Medvedev $(1,3,4)$, an internationally recognized geneticist now living in London, England. He concluded that the radioactive contamination zone (reported by 
Tumerman, 7) in Cheliabinsk Province was created in the winter of 1957-58 (3). He alleged that it resulted from a massive explosion at a military site where long-lived, high-level fission wastes had been improperly buried for many years $(3,4)$. Based on information obtained from Soviet radioecology studies, which he believed were conducted near the site of the catastrophe, Medvedev suggested (3) that the contamination zone contained in excess of $1 \times 10^{9}$ curies ( $\mathrm{Ci}$, a unit of radioactivity equal to $3.7 \times 10^{10}$ disintegrations per second) of ${ }^{90} \mathrm{Sr}$ (reference radionuclide) and extended over several thousand square miles. During a visit to our Laboratory (October 1977), he reiterated his contention $(3,4)$ that the location, year of occurrence, areal extent, and indeed, even the type of nuclear-related incident could be confirmed within reasonable limits by a critical analysis of the existing U.S.S.R. radioecology literature.

\section{PURPOSE}

The implications of a catastrophic release from a high-level fission waste storage facility seem obvious. We therefore conducted an independent analys is of the Soviet literature associated with radioecology and nuclear technology in order to resolve our own doubts about the exact nature and consequences, indeed even the occurrence, of the postulated incident. Because of some apparent inconsistencies, we originally believed that Medvedev could have reached completely incorrect conclusions about both the source and extent of the contamination zone in Cheliabinsk Province because of his unfamiliarity with radioecology and nuclear technology. A skeptic might argue that 
the radioecology study area was associated with a large radiochemical separations complex and resulted from imprudent, chronic releases of radioactivity over a long period. He might also suggest that Tumerman (7) observed a restricted area on the large reservation associated with a military plutonium production facility. It might follow that local residents had been relocated when the site was originally developed (Oak Ridge and Hanford experience) and the radiation warning signs actually represented a relatively low radioactivity level associated with chronic releases (designed to discourage unauthorized entry). Our secondary hypothesis was that Medvedev was trying to convey the existence of an actual historical nuclear incident, but that he had misinterpreted the scientific literature on which he reported (3), again because of unfamiliarity with the subject matter. Once we had seen the CIA release (8), however, it became apparent that the order of our hypotheses was probably reversed.

\section{SOVIET RADIOECOLOGY SOURCES}

A significant proportion of the contemporary Soviet radioecology literature has been devoted to field studies in an area which may actualiy have been accidentally contaminated (e.g., such as the "Kas $7 i$ area") although the site location is never provided in these publications (11-52). A pervasive characteristic of these works is the statement that the radioisotopes, moderate- to long-lived fission products (primarily ${ }^{90} \mathrm{Sr}$, but also ${ }^{144} \mathrm{Ce},{ }^{137} \mathrm{Cs},{ }^{106} \mathrm{Ru}$, and ${ }^{95} \mathrm{Zr}$ ), were experimentally applied once as carrier-free nitrate solutions $(14,16-18,34,40,43)$ to either soil or water surfaces, in quantities 
sufficient for accurate radiological analyses. [The radioisotope ${ }^{95} \mathrm{Zr}$ is mentioned only once in a footnote to a paper on the genetic effects of ${ }^{90} \mathrm{Sr}$ (17). The original applications in this case also included ${ }^{144} \mathrm{Ce},{ }^{106} \mathrm{Ru}$, and ${ }^{95} \mathrm{Zr}$, but these isotopes had decayed out in the 11-year period between application and data collection.] The reported level of application was typically between $0.3 \mathrm{mCi} / \mathrm{m}^{2}$ and $3.4 \mathrm{mCi} / \mathrm{m}^{2}$ (except for ${ }^{137} \mathrm{Cs}, 4-8 \mu \mathrm{Ci} / \mathrm{m}^{2}$, in association with $90_{\mathrm{Sr}, 0.6-3.4 \mathrm{mCi} / \mathrm{m}^{2} \text {, in terrestrial studies) }}$ over land and water areas which are often incredibly large (11-52) for experimental radioecological studies (stated areas up to $11 \mathrm{~km}^{2}$ ).

Reticence about site identification in ecological field research is most peculiar. It is standard practice to report both an accurate site location and a reasonable description of the biological community under investigation. The interested reader has only to scan the field studies reported in the 1977 issues of the Soviet Journal of Ecology and Radiobiology to verify this. The reader will also encounter papers by authors previously associated with "Kasli area" studies which make this point quite effectively $(53-55)$. In two cases $(54,55)$, data were obtained from an area immediately east of the dashed area drawn in Fig. 1 (near the centroid). This site may have served as the control area for "Kasli area" radioecology investigations. [We realize the possibility that military security restrictions might affect the identification by Soviet scientists of study sites associated with nuclear installations to a greater degree than in the United States.]

Research results reported by contemporary scientists at other locations in the U.S.S.R. (56-60) show clearly that such high levels 
(i.e., $\mathrm{mci} / \mathrm{m}^{2}$ ) were not required for accurate radiological analyses. In fact, the levels applied in this group of long-term field studies were, in many cases, either producing measurable genetic effects or demonstrably toxic $(17-19,34,35,38,39,49,51,52)$, which might confound studies of radionuclide transport: the stated object in the majority of cases. Further, the methods by which these large field sites were contaminated are not provided. [We recognize that in some cases, Soviet scientists have applied high levels (i.e., $\mathrm{mci} / \mathrm{m}^{2}$ ) to well-defined, small areas $(\leq 0.1 \mathrm{ha})$ in other unrelated radioecology studies for specific purposes, but these papers also contain a clear description of the application method as we11.]

The exclusive use of the nitrate form of the isotopes appears unusual in itse if since the isotopes were typically supplied as chlorides in our country (except zirconium, as the oxalate) for research purposes $(61,62)$. Radiostrontium chloride was the chemical form produced during removal of isotopic carriers (calcium, barium) (62). There would then seem to be no advantage in ecological studies in conversion back to a nitrate. Contemporary Soviet scientists, working at the Urals Scientific Center, report application of the isotopes exclusively as chlorides (except zirconium, as the oxalate) in other, unrelated radioecology studies (63-68), indicating that Soviet practice was probably not significantly different from our own. The nitrate form is that in which fission products were usually held during most steps in fuel reprocessing, other radiochemical separations, and high-level liquid waste storage $(61,62,69-85)$. [We understand that other western countries utilized different isotope production schemes 
than our country did, resulting in different chemical forms of isotopes supplied for research purposes (i.e., cerium chloride, strontium nitrate, and cesium sulphate in the United Kingdom, 74), but we feel that the reports of actual Soviet practice negate this alternative.] The reporting of data, often starting, at relatively long time intervals, i.e., $6,10,11,13$, or 14 years following contamination $(11-15,17,19,29,31,40,41,43,44,49,50,52)$ is also a common characteristic of this subset of Soviet radioecology publications. Results of eighteen studies $(12-19,31,40,41,43-45,48-50,52)$ which were published over a thirteen-year period, all indicate a starting date between 1957 and 1961, assuming no more than a one-year time $1 \mathrm{ag}$ between completion of data collection and publication of the results. The majority of these references indicate a date of contamination occurring in 1957-1958 $(12,14,16-19,31,41,43-45)$. There are internal inconsistencies in at least one series of related terrestrial radioecology papers $(20,22-25,27-33)$ about the exact date of initial contamination. However, the confusion is alleviated by the information provided by three independent references $(19,31,86)$. The combined information indicates that the terrestrial study area was first contaminated in the latter half of calendar year 1957. [The apparent inconsistencies noted may not represent deliberate obfuscation, but rather may indicate that the authors were relaying information provided to them by other sources.]

Both aquatic (41) and terrestrial radioecology (11,52) papers indicate that the isotope was originally applied in a single aerosol event, a critical revelation which supports an accident case. In one 
case the application was to a group of closed lakes (41-43,45-48), two of which had reported surface areas of $4.5 \mathrm{~km}^{2}$ and $11 \mathrm{~km}^{2}$, respectively. The radioisotopes applied were ${ }^{144} \mathrm{Ce},{ }^{90} \mathrm{Sr}$, and ${ }^{106} \mathrm{Ru}$ (no mention of ${ }^{137} \mathrm{Cs}$ ): initial ${ }^{90} \mathrm{Sr}$ concentration $\sim 1 \mathrm{mCi} / \mathrm{m}^{2}$ for the two lakes just described. In the other case, the isotope $\left({ }^{90} \mathrm{Sr}\right.$ alone) was applied to the canopies of two distinct forest types (30-60 years 01d) $(11,52)$. The implication that these inputs were part of planned artificial contamination experiments is unrealistic (our conclusion, but also see last page of reference 87 ).

The fact that the two lakes described above were part of a group of 13 (46) which were actually contaminated (10 of which had surface areas of $5 \mathrm{~km}^{2}$ to $30 \mathrm{~km}^{2}, 47$ ) further demonstrates the implausibility of a planned deliberate contamination experiment. An indication that not all the lakes in this group were heavily contaminated (perhaps only 2) is perhaps provided by a cryptic reference (88) in the Soviet text on Radioecology about "the situation in a certain region prior to the beginning of global fallout caused by accidental contamination of a water body [Our underlining]. Since the ${ }^{90}$ sr concentration in the water was rather low the water body was used for a variety of purposes (water supply, farming, etc.)." This reference is to a Soviet paper on ${ }^{90} \mathrm{Sr}$ behavior in the human food chain, associated with a contaminated Take, to have been presented at a 1966 IAEA Symposium, but which was later withdrawn prior to the symposium. However, it was still abstracted (Nuclear Science Abstracts) and referenced as a preprint (89). 
Another water body $(21,26)$ probably with at least a partially open drainage, contained a ${ }^{90} \mathrm{Sr}$ concentration in $1969(0.2 \mu \mathrm{Ci} / \mathrm{liter}$ in water) comparable to the two lakes described above at the time of their original contamination. Unlike the other two, it had obviously received ${ }^{137} \mathrm{Cs}\left({ }^{90} \mathrm{Sr}:{ }^{137} \mathrm{Cs}\right.$ activity ratio in water reportedly $8: 1$ in 1969). This large water body (our estimate of surface area, approximately $20 \mathrm{~km}^{2}$ ) either received much more airborne activity or direct liquid inputs because of close proximity to the release site. If described conditions in 1969 represented an equilibrium for ${ }^{90}$ Sr resulting from a single input in 1957 (not known), then the contamination zone associated with this one system alone could have contained a ${ }^{90} \mathrm{Sr}$ inventory of $1 \times 10^{6} \mathrm{Ci}(10)$. We are currently unable to determine whether this lake initially received ${ }^{90} \mathrm{Sr}$ and ${ }^{137} \mathrm{Cs}$ in proportions comparable to those reported previously for terrestrial areas $\left({ }^{90} \mathrm{Sr}:{ }^{137} \mathrm{Cs}\right.$ activity ratio $\left.>100: 1\right)$ or in nearly equal amounts typical of unseparated fission wastes (74) without a more detailed history of the water body and its drainage. The latter case seems the more reasonable one based on other Soviet experience $(57,90,91)$. [Should the former case hold, this one system and its downstream drainage could have contained on the order of $10^{7} \mathrm{Ci}$ of ${ }^{90} \mathrm{Sr}$ (reference radionuclide).]

For purposes of our analysis, we have assumed that this water body was contaminated as a result of the same event which resulted in aerosol contamination of the other 13 lakes and terrestrial areas described, but that a large fraction of its radioactivity may have entered in liquid, rather than aerosol, form and over a longer time period. We 
cannot dismiss the possibility that this large water body was primarily contaminated by a totally different mechanism (i.e., chronic leakage from storage versus acute accidental event). A portion of the estimated radionuclide inventory in this system could have been derived from incidental releases from reported plutonium production facilities (8) (i.e., reactors and/or radiochemical separations plants and/or waste storage areas, etc.). However, it would appear to require extreme negligence to explain a release of $10^{6} \mathrm{Ci}$ of ${ }^{90} \mathrm{Sr}$ (reference radionuclide) by such a mechanism, particularly to an open aquatic ecosystem. We are aware, however, of at least one case where in high concentrations of fission/activation products (including $0.01 \mu \mathrm{Ci} / \mathrm{liter}$ ${ }^{90} \mathrm{Sr}$ in water) have been maintained in a closed lake (size and location unknown) for many years, as a result of chronic discharges from a Soviet reactor complex which began operating prior to 1957 $(90,92,93)$. Thus, any judgment about the actual source(s) of radionuclides for this one large water body must be tempered with caution.

The location of the radioecology study area can be determined with in reasonable limits by combining fragments of information (i.e., fauna, vegetation, soil, etc) from the literature. For example, one publication (46), together with one of its own citations (94), indicates that the group of 13 lakes was located in the forest-steppe zone of the Central Belt and in the Eastern Urals between the cities of Cheliabinsk and Sverdlovsk. The author of this work was associated with the Sungul Nuclear Research Institute (75) when he produced his first publication on the subject in 1961 (48). The mamals, waterfowl, 
reptiles, amphibians, and fishes identified in the study area $(20,23,25,27,29,31,33,47)$ match exactly with those reported from the Urals region $(95,96)$. Further, the presence of marmals from the Siberian fauna $(23,27)$ combined with the major forest types $(11,12,14,15,18,33,50)$ again indicate that the location is on the eastern side of the Ural mountains. Within this area, the forest types also further define the locality to an area north of Cheliabinsk and south of Sverd lovsk $(95,97)$. One paper specifically places the terrestrial study area in Cheliabinsk Province (31). The particular set of soil-vegetation types studied are a.11 found together only near Kasli within this zone $(95,98,99)$ and along west-east paths (prevailing winds-westerlies and southwesterlies, 94, 98), $\leq 50 \mathrm{~km}$ long, which might be expected for radioactive fallout from airborne plumes generated by an accidental release from a site near Kasli.

One can arrive at an estimate of the minimum size of the area contaminated with $\sim 1.0 \mathrm{mCi} / \mathrm{m}^{2}{ }^{90} \mathrm{Sr}$ by several independent methods. For example, an estimate can be based on the interconnecting watershed-water area required for the three heavily contaminated lakes described earlier. Because of the high density of lakes near Kasli (> 100 within a $25 \mathrm{~km}$ radius) one could actually hypothesize a number of $50 \mathrm{~km}$-1ong contamination zones (not shown in Fig. 1) which fulfill the condition that 14 lakes (10 of which have surface areas between 5 and $30 \mathrm{~km}^{2}$ ) are either included directly with in the high-level contamination zone or would be contaminated by transfer via the Techa River drainage. A number of these zones would not have to exceed $10 \mathrm{~km}$ in width; all, however, contain at least some areas of present human 
habitation. The contaminated areas suggested, although much smaller than that described by Medvedev (several thousand sq. miles, 3), are still considerably greater than $100 \mathrm{~km}^{2}$ (by factors of 3-5) in order to fulfill these conditions. However, since specific, high contamination levels have been reported for only three lakes $(21,45)$, in order to make a truly conservative areal estimate, one can further limit the calculation to consideration of instances wherein only three lakes, surface areas 4.5,11, and approximately $20 \mathrm{~km}^{2}$ (open drainage), are found in close proximity. Conditions for this case are fulfilled at two locations: one north (Lake Sinara and two smaller lakes to the east) and another south (Lake Kyzyltash and two small lakes to its northeast) of the city of Kasli (Fig. 1). The southern area contains no evidence of any towns or villages on the most recent available maps north of Lake Kyzyltash; see later section on Remedial Measures. Using the smallest rectangular area wich would enclose each group of three lakes, we obtained values slightly in excess of $100 \mathrm{~km}^{2}$. The areal estimates would then have to be increased further in order to fulfill the condition that a reach of highway be included in the contamination zone (e.g., Tumerman's observation, 7$)$. Another method for making such an estimate, as Medvedev proposed (3), can be based on the area required to support a reasonable harvest of sixteen animals (number collected in one radioecology study, 23) from a healthy, free-living deer herd under the climatic conditions known to exist in this region of the Urals $(95,98)$. This would fulfill the constraint that all individuals had lived exclusively within the contaminated area. [Our expectation is that Soviet scientists probably 
collected a relatively small fraction of the deer population from an unenclosed area with in the "Kasli area" contamination zone; note that specimens were shot rather than trapped $(23,27)$. See additional discussion in Reference 10.] A third method involves examination of spatial separation between the major soil-vegetation types $(13-16,19,36,40,44,95,98)$ (pine forest on turf-podzolic soil, birch-pine forest on gray forest soil, birch-forb forest on leached chernozem soil, salt grasses on solonchak, etc.) which were subjected to long-term studies of radionuclide migration after the event. Each of the methods independently indicates a minimum size for the contamination zone of $\sim 100 \mathrm{~km}^{2}$ in surface area.

\section{PARTIAL CORROBORATION}

After analyzing the available evidence up to this point (from Soviet citizens, CIA release, radioecology publications), we concluded that a major airborne release involving moderate- to long-lived fission products (but, inexplicably, with most of the $137 \mathrm{Cs}$ removed) occurred at a site near the city of Kas $1 i$ (50 km radius) in the winter of 1957-58. Extensive ice and snow cover in the long Russian winter could have delayed significant transfer into soil and surface waters for up to five months (95). We further concluded that an extensive area $\left(\geq 100 \mathrm{~km}^{2}\right)$ was contaminated with high levels $\left(\sim 1.0 \mathrm{mCi} / \mathrm{m}^{2} 90 \mathrm{Sr}\right.$, chosen as reference radionuclide) of radioactivity. The zone of significant contamination appeared to have spread over a potential east-west distance of $50 \mathrm{~km}$. The width or orientation of the zone (north-south) could not be definitively ascertained; a reasonable 
estimate indicated that the total area of the contamination zone $\left(\geq 0.1 \mu \mathrm{Ci} / \mathrm{m}^{2} 90 \mathrm{Sr}-10\right.$ times the 1957-58 fallout background level, 59) might exceed $1000 \mathrm{~km}^{2}$.

Based on the activity levels reported and the areal estimates for the contamination zone, we estimated that, if the entire Soviet radioecology data set analyzed refers to a single event, the incident involved the release of approximately $10^{6} \mathrm{Ci}$ of ${ }^{90} \mathrm{Sr}$ (reference radionuclide). We could not dismiss the possibility of independent contributions from several types of events (permutations and combinations of accidents and non-accidents) or from complex releases associated with a single accident. Thus, the airborne contribution to the "Kasli area" contamination zone potentially could represent a relatively small fraction of the total, perhaps $10^{5} \mathrm{Ci}$ of ${ }^{90} \mathrm{Sr}$, if our "minimum" case holds $\left(\sim 100 \mathrm{~km}^{2}\right.$ - $\left.1 \mathrm{mCi} / \mathrm{m}^{2}\right)$. The critical missing piece of information is the history of the drainage associated with one large water body discussed earlier - in particular, the sequence of radionuclide inputs (and losses) as a function of time between 1948-1970. Due to the high population density in this region (the industrial Urals, 95) and the reported level of ${ }^{90} \mathrm{Sr}$ contamination alone $(100,101)$, the incident probably resulted in the evacuation and/or resettlement of the human population from a significant area. However, the estimated scale of the "Kasli area" event, both in terms of at least an order of magnitude smaller area affected and 3 to 4 orders of magnitude less activity released, is significantly different than that originally postulated by Z. A. Medvedev (3), partially confirming our previous hypothes is that he may have incorrectiy interpreted his literature sources. 


\section{REMEDIAL MEASURES}

One could reasonably expect that some of the research results arising from studies of the Kasli incident dealt with means for lessening environmental impact. Some work was directed toward reducing the uptake of fission products by food crops by different chemical treatments, plowing techniques, etc. $(13,36)$. In another case, radiation effects on conifer seedlings, produced by long-lived fission products incorporated in the surface soil layer (34), were examined as part of a feasibility study to convert agricultural areas, too highly contaminated for food production, to forestry uses. Some of the aquatic research studies were cited in later evaluations of the migration potential for fission products in water contaminated by nuclear explosives applied for peaceful purposes (102). Still another paper appears to have synthesized dosimetric information obtained after the incident to develop criteria for emergency plans specifically designed for radiochemical separations facilities (37). [The "Kasli area" environmental studies have apparently been ongoing long enough to generate new field experiments designed to answer specific questions raised by the initial research, particularly in relation to observations of radiation effects in certain invertebrate populations and tree species $(19,52,86,103)$. It also appears that certain other radioecology investigations which involve the application of elevated concentrations of highly toxic radionuclides either because of short physical half-life (104) or low fractional uptake from soil (105) have been conducted in the "Kasli area" contamination zone. These studies were all initiated in the period between 1964-1974.] 
Comparisons of high-resolution $(1: 250,000)$ maps of the area between Cheliabinsk and Sverdlovsk based on materials produced before (1936-1954) and after the accident (1973-1974), respectively, indicated the deletion of over 30 names of small communities (< 2000 population) with in the dashed area of Fig. 1. None of the names of towns and villages shown on the earlier editions with in the $70-\mathrm{km}-1$ ong southwest-northeast running arm of the dashed area appear on the later editions. A somewhat wider zone $(10-15 \mathrm{~km}$ vs $7 \mathrm{~km})$ runs in a southeasterly direction toward the Sverdlovsk-Cheliabinsk highway, generally along the Techa River; however, names of a few communities still remain in this area. A number of the communities whose names no longer appear had evidently grown to $\geq 2000$ population size by the late 1950 's as their presence on low-resolution atlases $(9,106)$ testifies (Boyevka, Yugo-Koneva, and Russkaya Karabolka in the northeast arm and Metlino and Asanova in the southeast arm of the dashed area in Fig. 1). Further, population centers in other parts of the region appear to have developed extensively in the same period: nowhere else in the Sverdlovsk-Cheliabinsk area has such extensive deletion of community names occurred. Collectively, this information could be construed to indicate the relocation of the human inhabitants from the area in a time frame consistent with the contamination incident.

other measures have apparently included modification of surface water flow patterns in the Techa River drainage in order to reduce the hydrologic transport of longer-lived fission products $\left({ }^{90} \mathrm{Sr}\right.$, in particular) out of the contamination zone. This undertaking may have contributed to the apparent confusion indicated in the CIA release (8) 
about dates and types of accidents, particularly if extensive use of explosives was employed in construction projects. Such projects may have $\mathrm{played}$ a significant role in relocating human inhabitants from the sou theast arm of the dashed area in Fig. 1. That is, the northeast arm (or a segment thereof) could represent the primary area contaminated by the radioactive plume resulting from the "Kasli area" accident. The origin of the plume seems to have been near the junction of Lake Kyzyltash and the Techa River. The orientation of the plume deposition zone is that wich one would expect for a winter event in this region: prevailing winds are southwesterlies $(94,98)$. Secondary transport of contaminated soil and snow by the wind, along with surface and ground waters, could further modify the shape of the original contamination zone, particularly near unforested areas which had been highly contaminated initially. Thus, the shape of the dashed area in Fig. 1 is somewhat more complex than one might expect from a single, simple plume release, but not necessarily inconsistent with that from a single release because of the considerations discussed above. [Neither can a complex release from a single site be ruled out.] The total area involved is approximately $1000 \mathrm{~km}^{2}$ (400 sq. miles), an order of magnitude less than that originally suggested by Medvedev (3).

Extensive changes in surface water characteristics have occurred with in the dashed area in Fig. 1. An additional area is located approximately $20 \mathrm{~km}$ north of Kasli, in the watershed between Lake Itkul and Lake Sinara; however, the alterations here may have been the result of contemporary operations at a nearby nuclear installation. The most interesting features on the latest map series are two new, large 
cascaded reservoirs (total surface area $\simeq 50 \mathrm{~km}^{2}$, approximately equal to that of Lake Irtyash) on the Techa River immediately downstream from Lake Kyzyltash, along with an associated canal system (Fig. 2).

The Techa River no longer drains from Lake Irtyash through Lake Kyzyltash (as indicated in Fig. 1). Water which would have flowed into Lake Kyzyltash from Lake Irtyash now is diverted into a canal (Fig. 2). The canal transfers water around Lake Kyzyltash and the two new reservoirs to a point downstream on the Techa River. A new drainage for Lake Irtyash has also been provided (through Lake Berdenish) into the same canal system. All former tributaries of the Techa, which entered in the reach between Lake Kyzyltash and the new reservoirs, now drain into canal systems and flows are similarly intercepted and diverted to a point well downstream. The canals discharge into the Techa at a point $10 \mathrm{~km}$ upstream (west) from the highway between Che liabinsk and Sverd lovsk.

The appearance of the two large cascaded reservoirs (non-power producing) in such a water-rich area can be interpreted as surprising in itself. The fact that these reservoirs and Lake Kyzyltash have been isolated hydrologically from the surrounding drainage area (hardly a typical practice) strongly indicates that they have been specifically designed to prevent a waterborne contaminant (such as ${ }^{90} \mathrm{Sr}$ ) from moving further downstream in the Techa River system. Combined with Lake Kyzyitash, the total surface area available for storage is in excess of $70 \mathrm{~km}^{2}$. If this system has been designed, as one could conclude, to contain contaminated water resulting from the "Kasli area" incident, the storage area may also be indicative of the scale of the 

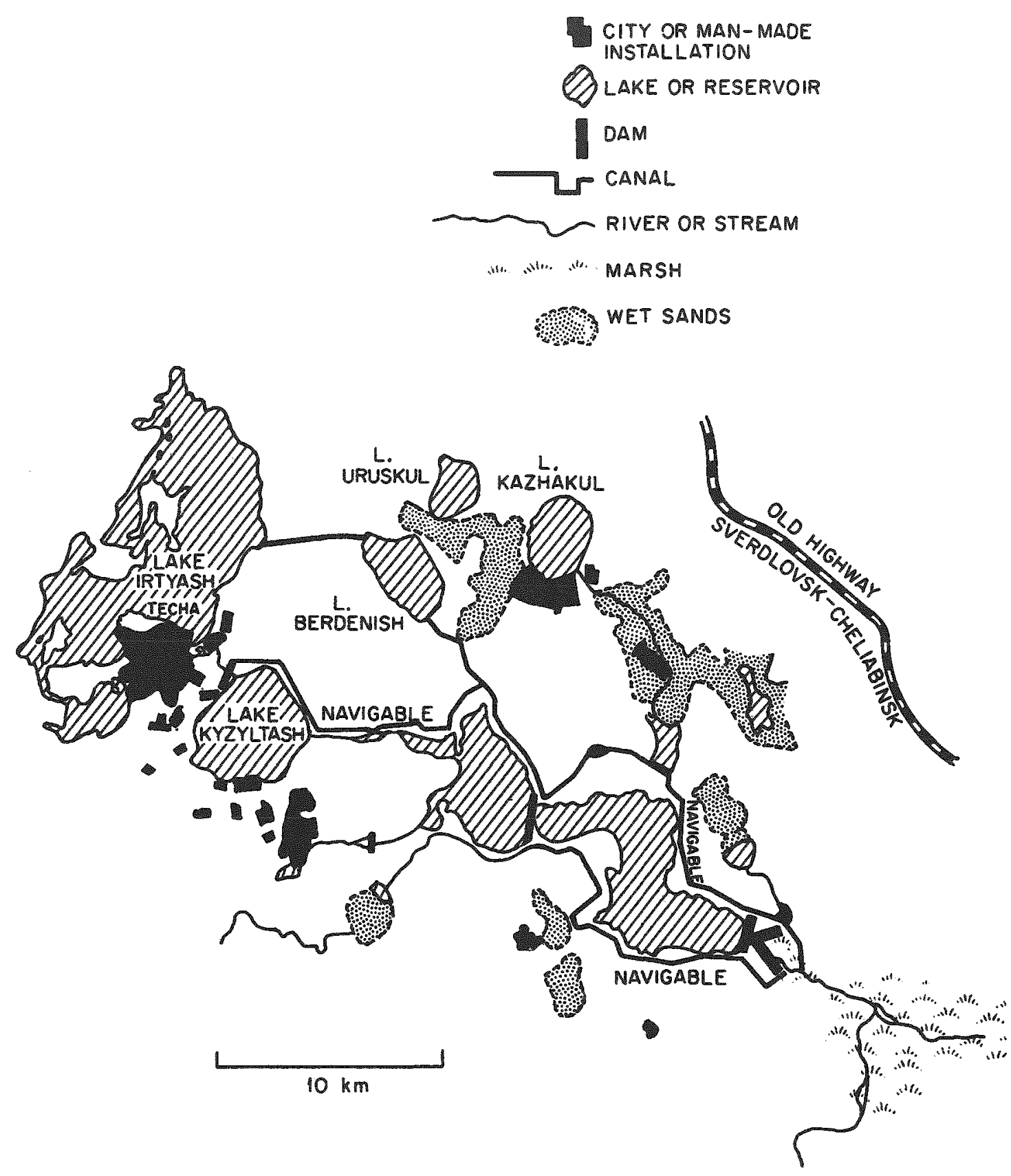

Fig. 2. Reservoir/canal system apparently constructed to reduce hydrologic transport of radioactive materials down the Techa River system. Map is based on post-accident (1973) features. 
original watershed/water surface wich was heavily contaminated. The presence of the reservoir storage system explains the absence of the city of Metlino and some smaller communities, which would have been inundated when the reservoirs were filled, but does not explain the disappearance of the majority of the small communities described previously.

Another significant observation is that the hypothesized primary plume deposition zone (northeast arm of dashed area in Fig. 1) contains three water bodies of the proper sizes and positions (Lakes Uruskul, Berdenish, and either Kyzyltash or first reservoir downstream) to explain those previously described in radioecology studies $(21,26,45)$. The centerline of the apparent plume deposition zone also intersects the Sverdlovsk-Cheliabinsk highway at a point $100 \mathrm{~km}$ from Sverdlovsk (recall Tumerman's observations reported earlier, 7).

The Soviet Union published its fish stocking records (as part of a fisheries improvement program begun in 1957) in the journal Voprosi Ikhtiologii (Problems of Icthyology). These records (107) provide additional information on the contamination zone in several respects. First, as expected, the lakes enclosed with in the dashed area in Fig. 1 have never been stocked, the object of the program being food production for human beings. The extension of the dashed area into Lake Irtyash was done to enclose the canal system described previously, not to indicate that we felt that Lake Irtyash was heavily contaminated by the accident. In fact, Lake Irtyash and nearly all of the lakes to its northeast (past Kasli up to the highway) have been stocked as part of the fisheries improvement program. Lake Itku1, Lake Sinara (108), 
and one of the two small lakes east of Lake Sinara have also been stocked. Lakes have been stocked virtually all around the periphery of the dashed area drawn in Fig. 1, but never inside. This seems to reinforce our previous conclusions about the extent of the presently impacted area based on other sources; i.e., that the total extent of the presently affected zone is not significantly larger than $1000 \mathrm{~km}^{2}$ as stated.

Significant physical changes may occur in populated areas over a time span of 20 to 40 years as a result of many factors: growth, changes in land-use patterns, development, etc. Thus, one has to be somewhat cautious about interpreting differences observed on a sequential time series of maps independent of other sources. However, we believe that the combined information presented is internally consistent, supports an accident case, further defines the scale of the event, and seems to contain far too many coincidences with other information sources to be explainable as a chance phenomenon.

\section{POTENTIAL CAUSES}

At least six potential types of events with in two major categories could be postulated to explain the "Kasli area" incident based on the present-day status of nuclear technology development. The two major categories are detonation of nuclear explosive devices (weapons test, weapons production accident, applications for peaceful purposes), and incidents involving aspects of plutonium production technology (reactors, radiochemical separations plants, high-level waste storage sites). In order to perform an evaluation of the probability that the 
"Kasli area" event was associated with one of these cases, one must consider three primary sources of information: historical development of nuclear weapons and reactor technology, inherent safeguards associated with each, and the radioactive "fingerprint" (array of fission products, relative concentrations, and inventories) characteristic of each individual source.

The "Kasli area" event occurred during a period of intense development and testing of both nuclear weapons and reactor technology. The intensity of this development was much greater in the U.S.S.R. than in the United States (109). The Soviet Union was racing to achieve nuclear weapons parity in this period near the height of the "Cold War." At this stage also, the two technologies were closely linked $(70,74,109)$. The reactors which had produced the buik of the existing fission product inventory at that time outside the U.S.S.R. were the near-natural uranium-fueled (aluminum clad or aluminum alloy), graphite-moderated, plutonium-producers, reasonably typified by those located at Hanford, Washington (74). Some heavy-water-moderated production reactors were also in existence by 1957 (110). Contemporary Soviet production reactors were believed to be similar in design $(75,109)$.

Assuming that Soviet developments in fuel reprocessing and high-level waste storage closely followed those in the United States, the U.S.S.R. would have had a large inventory (stored in large underground tanks) of both high-level wastes ( $\rightarrow 1 \mathrm{Ci} / 1$ iter fission product concentration) produced by solvent extraction (hexone and TBP processes) of uranium and plutonium, and intermediate-level wastes 
(< 1 Ci/liter) from an obsolete precipitation process (Bismuth Phosphate) designed for separation of plutonium alone, from fission products formed in irradiated fuel $(70-72,74,75,78-83,110)$. [Uranium was later separated from these wastes primarily by a TBP process $(74,111)$.$] Because of the high level of secrecy associated with early$ Soviet nuclear development, any analysis, particularly involving radiochemical separations and waste storage, is necessarily limited. Information must be gleaned from the relatively small number of open-literature publications available outside the Soviet Union $(75,109)$. Ironically, our only good reference on the subject is a 1966 Soviet biomedical research paper in which unseparated waste constituents are reported (112). The information presented indicates that the U.S.S.R. developed the sodium uranyl acetate precipitation process (113) for fuel reprocessing and, further, may have continued to use it into the $1960^{\prime} s$. The United States originally used the Bismuth Phosphate precipitation scheme for plutonium production (111), but discontinued it in the early 1950's $(110,114)$ because it was not as selective as solvent extraction, it did not recover uranium without an auxiliary precipitation (111) or solvent extraction (74) step, and waste volumes were relatively large (> 10 times those of later solvent extraction processes, 70). Two of the above objections apply to the sodium uranyl acetate process; however, uranium recovery was incorporated into the procedure (113). The presence of acetate in the first-cycle aqueous wastes may have represented a mixed blessing. On the one hand, its presence would seem to offer the possibility of a decomposition/concentration step which might allow considerable volume 
reduction and denitrification. The result could have been a highily concentrated, high-level liquid waste. An exothermic, potentially explosive (acetate-nitrate) reaction also looms under certain conditions if the concentration step is not carefully controlled. Fission product concentrations in unconcentrated first-cycle liquid wastes would typically have been in the 10-100 Ci/liter range (200 days decay after removal from a reactor). Thus, underground tank storage for a minimum of 3 to 5 years would have been expected before any of this material could have been reclassified as intermediate level. At that point, other waste storage/disposal techniques might have been considered (cribbing, earthen pit storage, deep wel1 injection, etc.) (115). [Cryptic information provided in a waste storage research paper, discussed later, leads us to believe that the Soviet Union may have also developed a solvent extraction process for ful1-scale use by 1957-58.]

One other significant difference known to exist was that the U.S.S.R. was engaged in production of selected fission products for agricultural and industrial use on a much larger scale than in the United States. For example, in 1958, the reported production of the long-lived fission product, ${ }^{137} \mathrm{Cs}$, was to exceed $1 \times 10^{6} \mathrm{Ci}$ (116). Contemporary U.S. production of all long-lived fission elements on an annual basis was an order of magnitude less; total production of all radioisotopes at Oak Ridge National Laboratory (the major producer) through 1957 was $3.3 \times 10^{5} \mathrm{Ci}$ (117). The cumulative production of ${ }^{137} \mathrm{Cs}$ through August 1959 was $<3 \times 10^{4} \mathrm{Ci}$ (118). 
NUCLEAR EXPLOSIVES ACC IDENTS

The "Kasli area" event predates serious consideration of the application of nuclear explosives in civil engineering (i.e., peaceful purposes - mining, reservoir construction, formation of underground cavities, etc.) (119). Although the incident occurred during a period of intense testing of nuclear weapons throughout the world, such testing was (obviousiy) carried out in areas remote from population centers. The cities of Cheliabinsk and Sverdlovsk comprised population centers of approximately 700,000 citizens each in 1959; average population density in Cheliabinsk Province was 3400 people per 100 $\mathrm{km}^{2}$ (95). This region was (and still is) a highly industrialized area of significant economic importance to the Soviet Union (95). In order to account for the total amount of ${ }^{90} \mathrm{Sr}$ which we estimate to be present in the "Kasli area" contamination zone (approximately $10^{6} \mathrm{Ci}$ ), one would require a 10 to 20 megaton (MT) yield device $(101,120,121)$, along with complete retention of ${ }^{90} \mathrm{Sr}$ (but not ${ }^{137} \mathrm{Cs}$ ) within the contamination zone - totally unrealistic. The total yield of a hydrogen bamb (MT class device) is the sum of the fission yield of the atomic bomb trigger, the thermonuclear yield of the fusion device, and the additional fission yield of $a{ }^{238} U$ blanket (if used). The ratio of fission yield to total yield may thus vary widely; however, we have assumed worst-case values of 0.5 to 1.0 for our estimate (121). Fission yields of ${ }^{90} \mathrm{Sr}$ and ${ }^{137} \mathrm{Cs}$ are comparable under all known conditions (122); ${ }^{90} \mathrm{Sr}$ yields relative to ${ }^{137} \mathrm{Cs}$ range from 0.36 to $0.93(122)$ as opposed to a relatively constant average ${ }^{90} \mathrm{Sr} /{ }^{137} \mathrm{Cs}$ 
ratio of 0.63 in wor 1d-wide fallout $(101,121)$. Because both isotopes have gaseous precursors, ancestor decay chains with similar properties $(59,121)$, and nearly identical half-lives (28-30 years), significant fractionation of ${ }^{90} \mathrm{Sr}$ from ${ }^{137} \mathrm{Cs}$ does not occur following large nuclear detonations $(101,119,121)$.

One can hypothesize a case involving accidental detonation of a smal1 ( $k T$ class) device at a combined weapons production/radiochemical separations/high-level waste storage facility. The detonation of a smaller device (kT) in a complex installation could produce radioactive contamination related to the facility rather than the device. That is, the accidental detonation of the nuclear device would represent the dispersal mechanism rather than the source of radioactivity. Since triggering devices are not installed at a weapons production facility, as an obvious safety measure, this case seems highly unlikely. Further, it may be unreasonable to conclude that the Soviet Union, which in 1958 had produced the world's first orbiting space satellite, would not have taken the precaution (as the United States did) of spatial separation of individual components of the weapons production process. The arming of a nuclear explosive device in close proximity to the facilities described above seems most improbable.

\section{PLUTONIUM PRODUCTION ACCIDENTS}

We seem inevitably drawn to the conclusion that the "Kasli area" contamination zone contains reactor-generated fission products associated with weapons-grade plutonium production. However, a case involving a reactor accident as the sole source would require 
essentially complete loss and deposition of the inventory of fission products from a reactor of the 1000 megawatt-thermal (MWt) class (Table 1) (also 74,125). The dominant isotopes present are short-lived materials (initial column in Table 1) (also true for weapon-produced materials, 102,122) not reported in any of the radioecology studies associated with the "Kasli area" incident. Had such a reactor accident occurred, there undoubtedly would have been no healthy forest ecosystems left for radioecologists to study near the site since radiation dose rates (already near or above damage thresholds for certain life-history stages of several tree species) would have been increased initially over two to three orders of magnitude above those actually reported. Further, reactors of the size required here did not reportediy appear in either Europe, Canada, the United States, or the Soviet Union until the early 1970's $(74,75,77,109)$.

Although it appears that one can dismiss the case of a reactor accident as the cause of the "Kasli area" event on the basis of quite simple considerations, one must introduce an additional caveat at this point: an important (perhaps obvious) one which applies to some extent to 211 cases which we discuss. To wit, we assume, despite obvious evidence of censorship about methods, site location, etc., that the actual scientific data presented in our Soviet references were factual and had not been deliberately altered in order to mask the occurrence of a specific type of incident, e.g., a reactor accident. A skeptic might again argue that collection of data (and radiochemical analysis of samples obtained initially) in radioecology studies had deliberately been delayed to allow the radioactive decay of short-lived 
Table 1. Ratios of individual reactor fission product activities to $137 \mathrm{Cs}$ ( $\mathrm{Ci}$ of F.P.:Ci of $137 \mathrm{Cs}$ ) for various decay times $(123,124)$

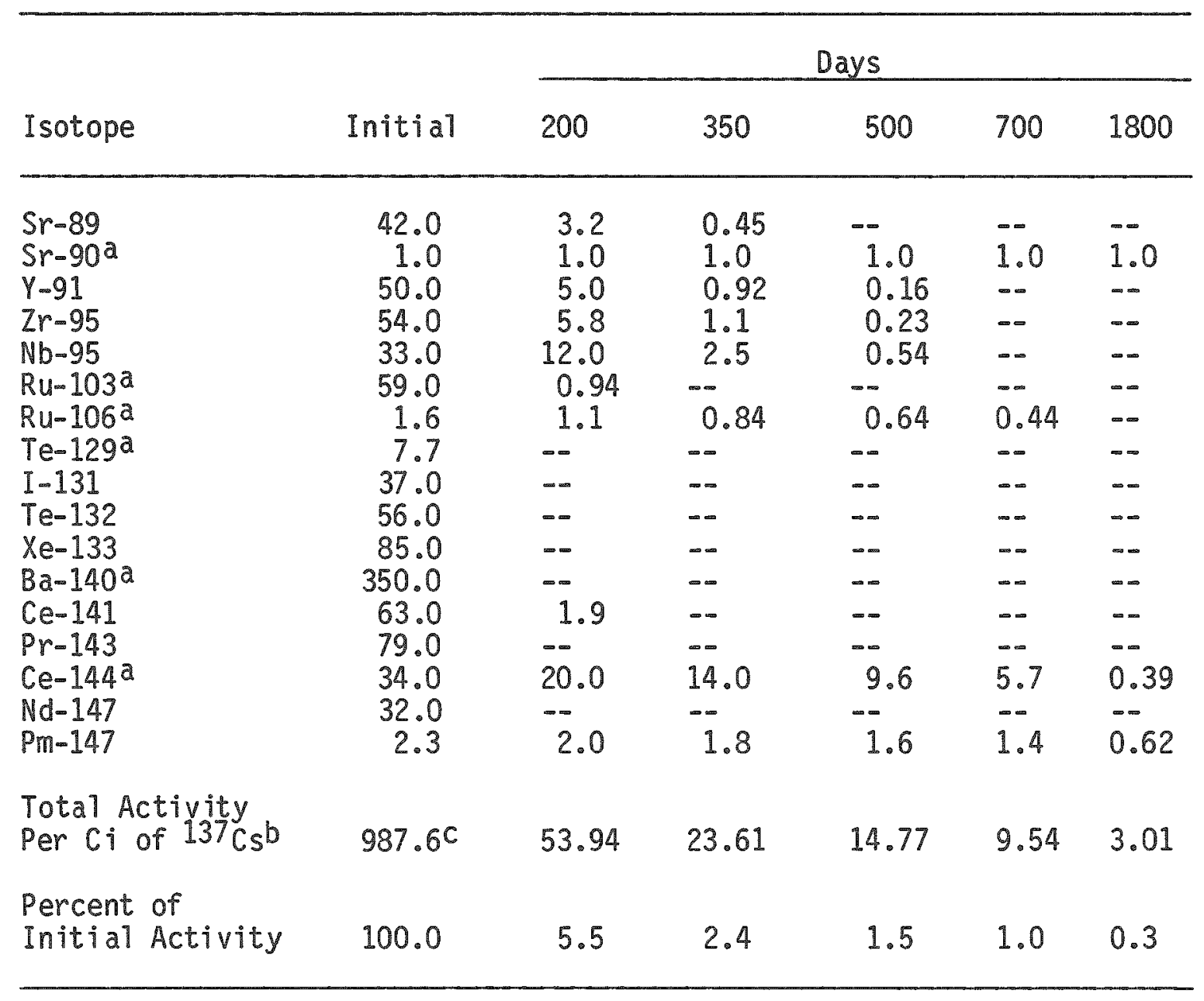

Includes daughter activity.

bFue 1 irradiation time - 100 days: $137 \mathrm{Cs}$ inventory of 1000 MWt reactor after 100 days operating time $-7 \times 10^{5} \mathrm{Ci}$.

cIncludes ${ }^{137} \mathrm{Cs}$ contribution. 
radionuclides. He might also suggest that terrestrial field work was carried out at locations remote enough from the reactor to permit the survival of forest ecosystems (e.g., areas of mixed forest where pines, but not birch, would be killed, 52) and, further, that references to applications of isotopes as carrier-free nitrates simply represented an attempt to allay suspicion about already-skimpy Experimental Methods and Materials sections of radioecology publications. The conspicuous reduction of ${ }^{137} \mathrm{Cs}$ relative to ${ }^{90} \mathrm{Sr}$ reported in field studies could be explained by a volatility mechanism: fractionation of cesium from less volatile elements (strontium, cerium, ruthenium) at high temperatures $(83,126)$ under accident conditions. This would have to be followed by the catastrophic release of the nonvolatile inventory. The presence of a large, classified (military security), prototype plutonium-production reactor at one of the "Kasli area" sites could provide both the required fission product inventory and the reason for concea iment.

Our argumentative skeptic might not agree, but we have no reason to believe that the scientific data have been falsified; in any event, additional evidence against a reactor accident case does exist. The catastrophic ejection of the entire nonvolatile fission product inventory of a nuclear reactor (even a Soviet prototype in 1957-58) in the sequence suggested above does not seem very credible. [The Windscale experience (U.K., October, 1957 which Soviet authors acknow ledge as the largest radioactivity release in reactor history, 100) would appear to be more typical; in this case (127), the principal fission products released were ${ }^{131}$ I $\left(2 \times 10^{4} \mathrm{Ci}\right.$ ) and ${ }^{137} \mathrm{Cs}$ (600 Ci; 
${ }^{90} \mathrm{Sr} /{ }^{137} \mathrm{Cs}$ activity ratio 0.015$\left.).\right]$ Meltdown of the fuel elements and, hence, at tainment of temperatures in excess of $1150 \mathrm{C}(83)$ would be a requisite in any event. At temperatures of $1227 \mathrm{C}$ and $1680 \mathrm{C}$, which are sufficient to melt aluminum $\mathrm{clad}$ and aluminum alloy fuel elements, respectively (83), both strontium and cesium are volatilized; cerium, but not ruthenium (metal) is also slightly volatile at $1680 \mathrm{C}$ $(83,126)$. The association of ${ }^{90} \mathrm{Sr},{ }^{106} \mathrm{Ru}$, and ${ }^{144} \mathrm{Ce}$ at appropriately high surface concentrations $\left(\mathrm{mCi} / \mathrm{m}^{2}\right)$ in certain "Kasli area" radioecology studies is not consistent with requirements of a fractionation mechanism based on differential element volatilities at high temperatures; i.e., that both strontium and cesium be significantly separated from cerium and ruthenium.

A catastrophic reactor accident of the hypothetical type required here would also result in the release and deposition of large quantities of plutonium and uranium. We estimate that the activity of ${ }^{239} \mathrm{Pu}$ released would have been approximately $1 \%(74,83)$ of the corresponding values for ${ }^{90} \mathrm{Sr}$. Because of its much greater toxicity $(74,125)$, plutonium, and not just ${ }^{90} \mathrm{Sr}$, would have been subjected to intensive study in the "Kasli area." The internal radiation dose contribution from plutonium could not have been ignored in radiation effects studies. We have found no mention of plutonium in the extensive "Kasli area" radioecology investigations (11-52). [This case would also require either that an extremely large area had been contaminated by ${ }^{137} \mathrm{Cs}$ (> 100 times that for ${ }^{90} \mathrm{Sr}$ ), or that overlap had occurred between high-level $\left(\mathrm{mCi} / \mathrm{m}^{2}\right){ }^{137} \mathrm{Cs}$ and ${ }^{90} \mathrm{Sr}$ contamination zones (caused by a shift in wind direction during the accident) in order to 
produce the ${ }^{90} \mathrm{Sr} /{ }^{137} \mathrm{Cs}$ activity ratios (> 100:1) reported in terrestrial radioecology study areas. If such ${ }^{137} \mathrm{Cs}$ contaminated areas actually existed one might legitimately ask three questions: first, why the obvious preponderance of ${ }^{90} \mathrm{Sr}$ research papers in the Soviet literature; second, why have Soviet scientists used data from their own long-term research on ${ }^{90} \mathrm{Sr}$ to forecast its migration in soils (44), but, in a similar exercise, used United Kingdom data (128) to forecast ${ }^{137}$ Cs migration; and, third, why are the first ${ }^{137}$ Cs data in long-term Soviet soil radioecology studies not reported till 10 years after application (14), while only ${ }^{144} \mathrm{Ce}$ and ${ }^{90} \mathrm{Sr}$ data are reported ear lier $(15,16)$ ?]

The radioactive "fingerprint" provided by the "Kasli area" field studies strongly implies an incident involving the radiochemical separations-waste storage aspect of weapons-plutonium production technology. The five radioisotopes $\left({ }^{95} \mathrm{Zr},{ }^{90} \mathrm{Sr},{ }^{106} \mathrm{Ru},{ }^{137} \mathrm{Cs}\right.$, and ${ }^{144} \mathrm{Ce}$ ) reported in these investigations become the dominant radioactive materials remaining in reactor-produced high-level liquid wastes after 1 to 2 years decay time following removal from a reactor (Table 1). [Zirconium-niobium-95 was often at least partially removed, both by "head-end" treatments and its tendency to plate out on the walls of tanks $(70,124)$. Observed ratios of ${ }^{90} \mathrm{Sr}$ in actual waste materials could be lower by a factor of $2{ }^{106}$ Ru might be increased by the same factor (124). Promethium-147, a low-energy beta emitter, while present in these wastes, would not ordinarily be reported in environmental studies since its dose contribution in such a mixture is negligible (125) and its concentration would not be determinable without a rigorous analytical effort (124).] 
Terrestrial radioecology studies report ${ }^{90} \mathrm{Sr} /{ }^{137} \mathrm{Cs}$ activity ratios in soil and organisms which are over two orders of magnitude greater (i.e., ${ }^{90}$ Sr concentration: ${ }^{137}$ Cs concentration $>100: 1$ ) than those present in unseparated fission wastes. While it is true that both of these isotopes are dominant radioactive components in long-lived wastes (> 5 years after removal from a reactor) (Table 1 ), the ${ }^{90} \mathrm{Sr}:{ }^{137} \mathrm{Cs}$ activity ratio is also essentially equal to unity. The fact that ${ }^{144}$ Ce was apparently the dominant isotope at the start of both soil $(15,16)$, terrestrial ecology $(17,52,86)$, and aquatic ecology (45) studies $\left({ }^{144} \mathrm{Ce}:{ }^{90} \mathrm{Sr} \sim 10: 1\right)$ argues against release of materials from a high-level waste facility after long-term storage. In one series of aquatic studies, ${ }^{106}$ Ru was also present at approximately the same level as ${ }^{90} \mathrm{Sr}$ at the start (45), and, again, there is no indication that ${ }^{137}$ CS contributed significantly to the total activity. These isotopic activity ratios are what one would expect in reprocessed fission wastes (allowing approximately 1-2 years decay time after removal from a reactor) if and only if $137 \mathrm{Cs}$ had been somehow separated from the remaining material (Table 1 ).

The data in Table 1 (coupled with observed variations in actual high-level wastes) indicate that an activity ratio for ${ }^{144} \mathrm{Ce}:{ }^{90} \mathrm{Sr}:{ }^{106} \mathrm{Ru}$ : ${ }^{137}$ Cs of approximately 10:1:1:1 actually holds true, within a factor of two, for the period from 200 days to 2 years. Thus, white the activity ratios reported in "Kasli area" studies agree well with those in reprocessed wastes for ${ }^{90} \mathrm{Sr},{ }^{106} \mathrm{Ru}$, and ${ }^{144} \mathrm{Ce}$, an intervening ${ }^{137}$ Cs removal mechanism is required to reduce its level to $<1 / 100$ that of ${ }^{90} \mathrm{Sr}$. [Waste storage containers would have been filled 
gradually over a period of time which would depend on tank volume, process volume, and production rate (72). Thus, the activity ratio described would have been an average value; some material in storage would have been aged a slightly shorter or longer time, respectively.]

\section{CESIUM SEPARATION MECHANISMS}

At least five potential explanations exist to account for the aberrantly low ${ }^{137} \mathrm{Cs}:{ }^{90} \mathrm{Sr}$ ratios (relative to typical high-level wastes) reported in the terrestrial radioecology data set we have analyzed. First, cesium might have been separated as part of the primary fuel reprocessing scheme. At least one plutonium separations procedure (ion exchange - zirconium phosphate columns) incorporated cesium removal (also ${ }^{95} \mathrm{Zr}$ ) in the primary step (129). However, we have found no reference to suggest that this scheme was developed anywhere past laboratory scale and, thus far, no mention of this process in the Soviet nuclear technology Titerature. [Evidence for the sodium uranyl acetate reprocessing method (and solvent extraction, discussed later) effectively negates this possibility.]

Second, separation of ${ }^{137} \mathrm{Cs}$ ( and ${ }^{90} \mathrm{Sr}$ ) from high-level wastes might have been attempted in order both to reduce the long-term hazards of stored wastes and the volume of storage required. Although this is a common practice with modern waste materials (110), according to our information $(61,74)$, separations for this purpose in 1957-58 had not advanced past the exploratory stage. [However, waste scavenging (involving precipitation, decantation of supernatant, and rinsing of the precipitate) is one mechanism whereby separation of ${ }^{137}$ Cs from 
${ }^{90} \mathrm{Sr}$ (by factors $>100$ to 1 ) and other fission products can be achieved $(62,69,74,130)$. This type of step could have been performed preparatory to a cesium isotope production process as we 11.]

A third case is derivable from the second: clean separation of the liquid (supernatant) containing $>99 \%$ of the ${ }^{137}$ Cs from a precipitate (sludge) containing $>99 \%$ of the ${ }^{90} \mathrm{Sr},{ }^{106} \mathrm{Ru}$, and ${ }^{144} \mathrm{Ce}$ in stored, neutralized high-level wastes by some accident mechanism which allows rapid leakage of the liquid out of containment and, then, atmospheric dispersal of at least a fraction of the sludge. This case is attractive because if the bulk of the precipitate followed the liquid (as a slurry) and then found its way into the previously described large water body (with the open drainage), while the other lakes and the terrestrial areas were contaminated by the aerosol phase, one would have a potential explanation for the "Kasli area" incident which would involve releases from only a single high-level waste container.

Fourth, the Russian nuclear technology literature indicates that ${ }^{137} \mathrm{Cs}$ was the initial isotope (and in 1958, the only product of significance both inside and outside the U.S.S.R.) removed from fission wastes for large-scale radioisotope production $(69,116)$. Presently, this would seem to be the best explanation for the marked reduction of ${ }^{137} \mathrm{Cs}$ in part of the "Kas $1 i$ area" contamination zone involving a deliberate separation accident.

A fifth possibility is that high-temperature conditions, produced by self-heating of drying, highly concentrated high-level wastes, caused the volatilization of most of the ${ }^{137}$ Cs prior to an explosion 
which vented the remaining materials. However, the volatilization case has two serious problems: one is the repeated reference to isotope application in the nitrate form in "Kasli area" radioecology studies and the other is the presence of ${ }^{106} \mathrm{Ru}$ as a significant (and apparently undiminished) constituent at the start of aquatic studies. A significant effort has been expended both in the United States and the Soviet Union directed toward conversion of high-level liquid wastes to solids (glasses, ceramic fusions, caicined alumina, etc.) for reasons related to safety, volume reduction etc. $(74,85,131)$. One product of this research has been detailed information on the volatilization of fission products at temperatures above $100 \mathrm{C}$. In acid preparations (most probable case based on reported Soviet practice in 1962,132, but see later discussion on dispersal mechanisms), ruthenium volatilizes at lower temperatures $(<400 \mathrm{C})$ than cesium (formation of $\mathrm{RuO}_{4}$ ). In basic (neutralized) mixtures, ruthenium volatilization may be suppressed at temperatures up to $900 \mathrm{C}$. However, volatilization of ${ }^{137} \mathrm{Cs}$ commences at temperatures of 400 to $500 \mathrm{C}$ near the decomposition temperature of its oxide. In neutralized high-level liquid wastes produced in solvent extraction (or sodium uranyi acetate, 113) processes, the dominant nitrates present ( $\mathrm{NaNO}_{3}$, $\mathrm{Al}\left(\mathrm{NO}_{3}\right)_{3}$, and $\left.\mathrm{NH}_{4} \mathrm{NO}_{3}\right)(70,71,74)$ would also be decomposed at temperatures less than $400 \mathrm{C}(133)$. [Some arguments applied earlier both for and against a reactor accident can be applied to the waste volatilization case, as well.] 


\section{PROBABLE SOURCE}

The volume $(70,72,77,78,114)$, radioactivity, and corresponding energy content of nitrate containing high-level wastes (several hundred - several thousand $\mathrm{m}^{3}$ ) held in a single underground storage tank could be sufficient to produce the level of contamination associated with the "Kasli area" event (and, in some historical cases, provide considerable explosive force for its dispersal if somehow released). This would have been the only source which could have provided the required inventory of moderate- to long-lived fission products in a single point release based on U.S. radiochemical separations/high-level waste handling practice in 1957-58 (72,74).

\section{POTENTIAL DISPERSAL MECHANISMS FOR HIGH-LEVEL WASTES}

One can postulate accident cases wherein, either as a result of a violent conventional explosion/fire following either a nuclear criticality (superheating effect), or ignition of highly flammable solvents, or deflagration/detonation of certain historical nitrate wastes, or detonation of radiolytically produced hydrogen gas, or even steam pressure build-up (from radiolytic decay heat) in a high-level waste storage system associated with a radiochemical separations plant, a large quantity of fission products could be dispersed to the atmosphere. One could not necessarily infer the exact cause of the accident based on the reported isotopic ratios in the high-level contamination zone. Once again, the isotopic content is determined by the materials released rather than the dispersal mechanism. 
The explosive potential of diethyl ether, nitromethane, and certain other highly flamable solvents considered for certain solvent extraction applications in fuel reprocessing $(75,81,82)$ was well known and it seems doubtful that these would have been used in ful1-scale operations. Because of the apparent dissimilarity between Soviet and U.S. reprocessing schemes and rates of fission product development for agricultural and industrial uses which we reported earlier, one obviously cannot absolutely rule out the possibility that other significant differences in radiochemical separations techniques also existed, however improbable they might seem at present. The association of large volumes of solvents with large volumes of high-level wastes (spatially) is still highly unilkely.

At this point in the separations/storage process, fissionable material should not have been present in significant quantity, an argument against a nuclear criticality dispersal mechanism. Conditions of tank storage should have been unfavorable for a sustained criticality. In further support of this point, criticality incidents associated with radiochemical separations in contemporary U.S. experience (to the "Kasti area" incident) did not occur in materials containing fission products (134). Neither explosions nor significant quantities of long-lived fission products were produced in these incidents.

Despite the presence of large quantities of fission products held in U.S. high-level waste storage tanks, no incidences of fires, explosions, or significant atmospheric radioactive releases had occurred through $1975(114,134)$ (or have since occurred, to our 
knowledge). The relatively few failures had involved either corrosion or flexure of the steel tank liners, but without catastrophic leakage of the contents because of built-in safeguards $(114,134)$. Contemporary experience with radiochemical separations outside the Soviet Union had involved a few explosions and fires (of very limited extent) associated with evaporators, ion exchange columns, etc. $(134,135)$. Three of the four reported explosions involved evaporators $(134,135)$; only one occurred in association with significant fission product activity (135). The possibility of an incident associated with large-scale radioisotope production seems enhanced by the fact that in 1957-1958 the major ${ }^{137}$ Cs separations scheme employed the ammonium alum process $(62,69,74,117)$. This process fulfilled all the requirements for a large-scale production process stated by Soviet authors (69) in what appears to be the first comprehensive paper on the subject published outside the U.S.S.R. This first Soviet paper (69) did not provide a ${ }^{137}$ Cs production scheme since ${ }^{137} \mathrm{Cs}$ had already been separated from the material supplied to these investigators (the alum process was the only production method referenced, 62). The importance of the ammonium alum process is that resulting wastes, if left untreated, could then contain significant quantities of armonium nitrate [certain hexone solvent extraction process wastes also shared this feature prior to further separations) $(70,74,80)]$. In the United States, the ammonium alum process for ${ }^{137}$ Cs removal formed only an intermediate step in the fission product separations scheme $(62,114)$. Storage of large volumes of high-level wastes containing ammonium nitrate, following this step, was not practiced in the United States. The Soviet 
literature suggests that this might have been the case, following ${ }^{137}$ Cs separation, in the U.S.S.R. in $1958(69,116)$. Separations schemes for other long-lived fission elements were under development, but not beyond bench-scale facilities. It was recommended in any case that wastes be held for 2 to 2.5 years prior to isolation of isotopes such as ${ }^{90} \mathrm{Sr}$ and ${ }^{144} \mathrm{Ce}$ from reactor wastes $(69)$.

The explosive qualities of ammonium nitrate have been well recognized, but perhaps less well known is the fact that it forms a major ingredient in many slurry explosives (136-138). Ammonium nitrate is generally thought to be relatively insensitive to accidental detonation. However, at least five major disasters have involved accidental detonation of solid fertilizer-grade ammonium nitrate by apparently spontaneous mechanisms $(136,139)$. A chemical explosion occurred at the Chalk River Nuclear Research Laboratories in 1950 in a pilot plant evaporator used to concentrate fission products from a nitric acid-ammonium nitrate solution (135). The cause was determined to be "the buildup of too large a concentration of ammonium nitrate in the hot evaporator concentrate." Thus, a precedent already exists for a radioactive waste explosion when significant quantities of ammonium nitrate are present. [We must (again) point out that we have no direct evidence that the U.S.S.R. was using the ammonium alum process for ${ }^{137}$ Cs separation in 1957-58. Ammonium nitrate could likewise have been present in high-jevel wastes for a number of reasons. It could have been formed as a result of precipitation (74) or neutralization (70) steps, or it may have been used as a salting agent in soivent extraction $(70,140)$. Further, the Soviet Union was reportedly 
developing the nickel ferrocyanide cesium extraction process in 1957 (141); this process was also under development in the United States at the same time (61). In our case, the nickel ferrocyanide process had not been carried beyond pilot-scale facilities (74). We cannot rule out the possibility that the U.S.S.R. abandoned (or ignored) other cesium separations processes in favor of the nickel ferrocyanide procedure.]

\section{ACCIDENT SCRIPTS}

Based on the available evidence and the assumption that Soviet practice was similar to that in the United States in 1957-58, we will propose two independent explanations for both the initiation and expression of the "Kasli area" accident. Both ultimately involve explosions/fires in high-level waste residues contained in tank storage. In U.S. practice, high-level waste tanks were double-walled systems (concrete she 11 with sidewall and bottom lined inside with steel; top made of concrete, often with a thick layer of earth overhead). Some tanks had both a primary internal cooling system to prevent boiling and a backup system (air-cooled reflux condenser) in the tank top to prevent liquid ejection, should boiling occur. In these tanks, air was flushed continually to prevent hydrogen accumulation. Other tanks allowed controlled boiling of the liquid wastes (agitation by airlift circulators) and used a single condenser to return condensate to the tank. Air which exited 211 tanks was filtered to remove radioactive particles. Tanks were constantly monitored for a variety of conditions. If a leak was detected in one tank, its contents could be pumped into 
another. Some tanks were designed with a "cup and saucer" arrangement whereby liquid leakage from the inner "cup" could be retained by the outer "saucer" (114).

The initiation of our proposed accident would require that at least two, perhaps even three, of the primary cooling/safety mechanisms failed simultaneously and, further, that the failures went undetected (or at least unremedied) while conditions led to dispersal of the tank contents. Based on U.S. experience in 1957-58, it is difficult (for us) to see how anything but an "act of God" could have accomplished this. Our imaginary skeptic (now converted to a waste storage phenomenon rather than a reactor accident) might argue that the U.S.S.R. either did not incorporate all of our safety features into their waste storage practice or utilized a radically different type of storage system.

Both of the skeptic's suggestions may have merit, but, for the moment, let us assume that failure of safety mechanisms has occurred on a U.S. design storage tank and proceed from there. For tanks which kept wastes cooled below the boiling point, we will assume that the air purge system failed; this allowed the buildup of a high concentration of radiolytic hydrogen $(72,77,85,110,114)$ which then ignited and exploded. In the case of a "boiling waste" tank, we will speculate that the air-lift circulator failed; this led to the periodic occurrence of the "bumping" phenomenon (an irregular, violent boiling effect, apparently exacerbated by the presence of precipitates in neutralized wastes) $(72,78,110,114)$. Our calculation of the possible energy release from a hydrogen explosion (typical container dimensions up to 
several thousand cubic meters, worst-case conditions) and the maximum observed value for the "bumping" phenomenon (78) are both quite similar, $\sim 10^{6} \mathrm{kcal}$. The tank pressurization produced by ignition of radiolytic hydrogen or steam release via the "bumping" phenomenon might cause failure of the cooling systems and other safety devices and/or a breach in container integrity, but would hardly be sufficient to totally destroy the tank or to produce atmospheric dispersal of the contents. Likewise, design criteria sufficient to prevent container rupture, at least by the "bumping" phenomenon are now we 11-known $(77,78,110,114)$.

However, in U.S. practice, tank pressurization by irregular, violent boiling was discovered "under operating conditions different from those for which the storage tanks were originally designed. Hence, the existing structures had to be carefully evaluated to determine the amount of internal vapor pressure they could safely contain. Steps were taken to insure that this pressure was not exceeded" (114). Thus, in the United States, early experience with high-level wastes played a major role in determining both the structural design of later high-level waste storage tanks and the types and degree of application of safety mechanisms (114). If the U.S.S.R. (with a lesser degree of experience in 1957-58) had attempted to use less conservative design criteria for waste storage tanks (or different structural designs, etc.) than the United States, one might reasonably speculate that "the discovery" of this phenomenon might have occurred under less satisfactory circumstances. Depending on whether (and where) a breach in the container occurred, the initiation event might have been accompanied by 
either complete loss of the liquid contents directly into the surrounding soil, or a fractional loss via a geyser of steam and boiling liquid into the air (and over the soil) through the top of the tank, or essentially no loss of the liquid inventory. Liquid remaining in the tank would begin to self-concentrate, and solid residues (from neutralized wastes), if unaccompanied by liquid, could begin to superheat because of radioactive decay. The initiation event thus could incorporate a significant liquid release to the environs, but would not be expected to produce the required atmospheric release to explain the "Kasli area" incident.

The ultimate expression of the accident could have occurred when superheating of slurries or solid residues left in the tank produced either a deflagration resulting from reactions between nitrates and excessive amounts of organic contaminants (solvent decomposition residues (117), perhaps acetate, etc.) or a detonation of ammonium nitrate-containing wastes. The potential energy release would be up to $10^{3}$ times greater than that for the initiation event (e.g., $0.1 \mathrm{kT}-$ TNT equivalent, $\sim 1 \times 10^{9} \mathrm{kcaT}$; initial condition $-2 \mathrm{M} \mathrm{NH}_{4} \mathrm{NO}_{3}$ in $1000 \mathrm{~m}^{3}$ tank, 2/3 fu11, 140). A violent explosion in one waste storage tank could breach the containment of a companion tank (usually arranged in groups called "farms") by ground shock; thus, a simultaneous atmospheric and liquid release (i.e., from the companion tank) of high-level radioactive wastes with significantly different radionuclide contents could occur. A tank breach/liquid leakage/aerosol-dispersalof-precipitate case (discussed earlier - third cesium separation case) would require the involvement of only a single tank to produce a liquid 
release with a ${ }^{90} \mathrm{Sr}:{ }^{137} \mathrm{Cs}$ activity ratio of $\sim 1: 1$ and an aerosol release with a ratio $>100: 1$. This would seem to offer at least two possible mechanisms for contamination of the entire "Kasli area" zone, with its apparently disparate ${ }^{90} \mathrm{Sr} /{ }^{137} \mathrm{Cs}$ ratios (one large water body vs other lakes and terrestrial areas) as a result of a single event. However, the mechanism for precipitate (sludge) dispersal in the latter case escapes us at present since the bulk of the nitrate-organic or ammonium nitrate fraction should accompany the liquid and not remain with the precipitate. However, this latter case may still have merit in light of the discussion which follows.

\section{ANOTHER VIEWPOINT}

Although acid storage of high-level waste concentrates in stainless steel tanks, presumably without sludges, was reported to be typical Soviet practice in 1962, this may have referred only to wastes produced by newer solvent extraction processes (132), i.e., not from the sodium uranyl acetate process. In a research paper (presented at a 1958 Geneva Symposium) related to the feasibility of storing high-level wastes in open, earthen reservoirs (142), Soviet scientists reported data on the migration of mixed fission products in soils using two distinct types of model solutions [alkaline, $2.4 \mathrm{M} \mathrm{NaNO}_{3}$ and acid, $\left.1 \mathrm{M} \mathrm{Al}\left(\mathrm{NO}_{3}\right)_{3}\right]$. The alkaline solution could have been a model for neutralized, high-level wastes from either the sodium uranyl acetate precipitation process or a TBP-type solvent extraction method. The aluminum nitrate-containing solution most certainly represented a solvent extraction waste (probably from a hexone process, 70,71 ). Aluminum 
nitrate was used as a salting agent $(70,140)$ and waste storage in acid form (in stainless steel tanks) was often practiced because neutralization significantly increased storage volumes (70).

Further, the alternative of long-term storage of high-level wastes in sma11, surface reservoirs of earth (both lined and unlined) appears to have at least been seriously explored by the U.S.S.R. (if not implemented) because of economic considerations (142). An intriguing series of related laboratory studies on the potential use of unlined, low flow rate, cascaded reservoirs for deactivation and disposal of radioactive wastes was published in the late 1950-mid 1960 period (143). The initial results generated optimism about the efficacy of such systems for generalized radioactive waste disposal. Later papers focussed on optimizing cesium/strontium radioisotope removal by manipulation of physical and biological characteristics and identified a potential problem with transport of radioactivity out of such systems by desorption phenomena. In the one known field test of an unlined system (142), a gully ( $3 \mathrm{~km}$ long) was simply dammed and wastes were directly discharged into it. This system failed rapidly because of radionuclide migration (primarily ruthenium, but also strontium and cesium isotopes) into ground water (142).

Thus, al though the Soviet Union has reportedly employed tank storage for its high-level wastes $(77,132,144)$, one cannot presently eliminate the possibility that the "Kasli area" event was caused by the catastrophic failure of an early, experimental waste disposal project involving some other type of container. For example, storage of high-level wastes in asphalt-lined pits was considered for a time in 
the United States, but was abandoned when research indicated potential problems with overheating and radiation damage in the asphalt liners (145). Subsequent research on bituminization (incorporation into asphalt) in the U.S.S.R. has also shown that high-level waste materials may not be stored in asphalt without auxiliary cooling and, further, that potentially explosive reactions may take place when waste nitrate-asphalt mixtures are allowed to reach temperatures of $300 \mathrm{C}$ (146).

Another speculative source in the U.S.S.R. may have been from a porous underground geologic formation into which high-level wastes may have been pumped for disposal (76). However, perhaps because of the inherent hazards recognized for this method of high-level waste disposal (76), reported Soviet practice prior to $1972(77,84,144)$ had involved injection of only low- and intermediate-level wastes into porous geologic formations. [What we have reluctantly concluded from all of this information is that just what "typical Soviet practice in either radiochemical separations or high-level waste storage" was in 1957-58 is still open to considerable speculation. The potential for accidents and chronic leakage associated with earthen reservoir storage of liquid high-level wastes appears to have been much greater than for controlled tank storage. Mechanisms for aerosol dispersal and cesium separation would also be more varied because of soil interactions. However, the relationship of these additional phenomena to an analysis of hazards associated with the historical development of nuclear technology outside the U.S.S.R. seems rather periphera1.] 
ADOITIONAL SUPPORT FOR HIGH-LEVEL WASTE ACCIDENT

Potential failures of safety mechanisms (cooling systems) on high-level liquid waste storage tanks resulting in evaporation and drying have long been recognized as a significant hazard $(72,77,85)$. Soviet authors appeared to be particularly concerned with the potential for explosions resulting from such failures in a paper (85) delivered at the IAEA Symposium on the Disposal of Radioactive Wastes held in 1959 .

Further evidence in support of an incident involving airborne release of separated radioactive wastes from a radiochemical separations/high-level waste storage facility is provided by a Soviet paper (37) presented at another IAEA Symposium (Handling of Radiation Accidents) held in 1969. The stated purpose of this paper was to determine criteria for systematic evacuation of areas accidentally contaminated by long-lived fission products (aged 200-350 days) from a radiochemical separations facility. The paper reports the results of a planned experimental contamination of field plots for subsequent dosimetric measurements (length of study - 3 months). However, the large size of the study area (indicated by the variety of physical and land-use features; e.g., haystacks, forest plots, asphalt highway, water bodies, collective farms, etc.), presence of contamination on clothing of collective farm workers, data on human inhalation and ingestion, and data for various seasons again suggest the implausibility of a planned experimental event. Additionally, the authors provide data for differential contamination of various terrestrial surfaces as a result of the passage of a radioactive cloud, 
methods or references not provided. This dosimetric study has been reported as the source of radioactive contamination subsequently utilized in a series of "Kasli area" terrestrial radioecology investigations. However, early works in the radioecology series were ongoing $(20,30,31) 3$ to 9 years before the stated date of contamination of the territory, - an apparent internal inconsistency.

\section{SUMMARY AND CONCLUSIONS}

It would seem that one can postulate a credible accidental release of separated fission wastes from high-level liquid waste storage associated with a Soviet radiochemical separations plant in 1957-58 by conventional means, i.e., without having to resort to any type of nuclear explosive or criticality mechanism. One such accident could have involved the detonation of a large volume of dried high-level wastes (containing significant quantities of ammonium nitrate), from which most of the ${ }^{137}$ Cs had been deliberately separated, following failure of a cooling system on a high-level waste storage tank. Based on present information and the assumption that Soviet practice was similar to that in the United States, it would seem that the only significant alternatives to be considered are additional venting mechanisms (e.g., fires/explosions involving other types of nitrate wastes, or perhaps even rupture of containment by steam pressure) which could result in the combined atmospheric/liquid release of separated, reprocessed fission wastes (approximately $10^{6} \mathrm{Ci}$ of ${ }^{90} \mathrm{Sr}$ - reference radionuclide) from a typical storage vessel. Cases involving detonation of nuclear explosives or reactor accidents (note the pervious caveat) 
appear to deserve little consideration as the sole source of the "Kasli area" contamination zone. The available evidence has firmly convinced us that a major release of fission products from a "Kas $1 i$ area" installation did occur, regardless of the cause.

Many different types of accidents could be postulated to explain the atmospheric/liquid release of radioactive materials from a high-level liquid waste storage facility in addition to those discussed; most would not be credible based on U.S. practice or experience. We have not specifically considered accidents whose causes are essentially unrelated to the technology and could not be deduced without an onsite forensic analysis (e.g., gross human error, natural disasters, or sabotage). What we have been particularly concerned with are those potential accident mechanisms perhaps inherent in the historical development of the technology. We also have not seriously attempted to analyze a situation involving multiple accidents, combinations of accidents and non-accidents, or a complex single event because we feel that all the potential causes under discussion contain considerable speculation already; further additions at this time seem pointless. We have singled out the ammonium nitrate waste-explosion case because it combines a seemingly credible dispersal mechanism cons istent with observations of cesium separation in the terrestrial contamination zone. We reiterate that this is not the only reasonable explanation for the "Kasli area" incident and that actual confirmation of the cause must awa it release of more information by the Soviet scientific community. We are presently unable to reconcile the allegations of large numbers of civilian casualties made by Medvedev and Tumerman $(3,4,7)$ 
with the reported concentrations of radioactivity in "Kasli area" radioecology studies. Our estimates of radiation dose rates for the $1 \mathrm{mCi} / \mathrm{m}^{2}-{ }^{90} \mathrm{Sr}$ reference surface concentration, using several potential mixtures of 200- to 350-day-01d reactor fission products (worst case, relative abundances from Table 1), are a small fraction of those delivered to inhabitants of the Marshall Islands, who were accidentally exposed to fallout radiation following a nuclear test in the Pacific (Bravo shot - Operation Castle, 147) in 1954. By analogy with the absence of casualties and the types of effects observed (147), we would conclude that prompt evacuation and personnel decontamination in the "Kasli area" should have prevented the development of acute radiation sequelae (primarily skin burns in this case). [Skin lesions produced by direct deposition on human skin are far less likely in Siberian residents in the winter than in Marshallese inhabitants under tropical conditions.] Thus, it seems quite reasonable to us that severe injuries and casualties, if any, may have been restricted to the nuclear installation at which the accident occurred. Nonetheless, present uncertainty about the exact distribution pattern of contamination from the accident, 1957 population patterns near the release site, residence time of the human population in the contamination zone (post-accident), isotopic content and particle size of the source material, and the actual circumstances surrounding the event (time, meteorological conditions, etc.) seriously limits a complete assessment of the human consequences of this incident. Again, we believe that this must await the release of more information by sources in the Soviet Union. 
We encourage independent evaluation of the bibliography we have presented as we 11 as the addition of any new information on the event. This incident appears to raise safety questions related to historical radioisotope separations and subsequent high-level liquid waste storage which should be answered. While we believe that the "Kasli area" phenomenon resulted from use of now-obsolete waste storage-isotope separation techniques, it has not been our objective to totally dismiss this incident as a historical event which could never reoccur, but rather to provide a vehicle whereby we can eventually obtain more information. It seems most probable to us that the eventual truth of the matter will be that modern high-level waste handling practices (denitrification, conversion to anhydrous melts or solid matrices, etc.) would have prevented this incident.

It seems rather apparent that the Soviet nuclear program has had to contend with a catastrophe involving reprocessed nuciear wastes. The extensive body of publications in the open literature indicates the seriousness with which the Soviet scientific establishment viewed the problem. However, the reluctance to provide detailed information about the nature of the source, site, etc., coupled with the probable existence of more research, documented but internal to the Soviet Union, limits the usefulness of the experiences gained by Soviet scientists: ecologists, health physicists, civil engineers, nuclear technologists, etc. As scientists deeply involved in evaluating hazards associated with radioactive releases to the biosphere, we urge the Soviet scientific community, which was engaged in the aftermath of the "Kas $1 i$ area" incident, to share all pertinent information with other 
scientists concerned with achieving the safe development of world-wide nuclear power. Soviet experience gained during the application of remedial measures on an unparalleled scale following this accident is clearly unique and would be invaluable to the remainder of the world's nuclear commun ity. 


\section{REFERENCES}

1. Z. A. Medvedev, New Scientist 72, 264 (1976).

2. Evidence on the Urais incident, New Scientist 72, 692 (1976).

3. 2. A. Medvedev, New Scientist 74, 761 (1977).

4. Z. A. Medvedev, New Scientist 76, 352 (1977).

5. P. Stubbs, New Scientist 76, 368 (1977).

6. S. White, New Scientist 76, 547 (1977).

7. W. E. Farre11, Ex-Soviet Scientist, Now in Israel, Tells of Nuclear Disaster, New York Times, December 9, 1976, p. 8.

8. Enclosures attached to reply from G. F. Wilson, Central Intelligence Agency, to request by R. B. Pollock, Citizen's Movement for Safe and Efficient Energy, for information relating to a nuclear disaster alleged to have occurred in the Ural Mountains in the Soviet Union in 1958, November 11, 1977.

9. Glavnoye Upravlyeniye Geodesii i Kartografii, AtTas SSR, (MVD SSR, Moscow, USSR, 1955) (In Russian).

10. J.R. Trabalka, L. D. Eyman, F. L. Parker, E. G. Struxness, and S. I. Auerbach, Another perspective of the 1958 Soviet nuclear accident, Nuclear Safety 20, 206 (1979).

11. R. M. Aleksakhin, L. R. Ginzburg, I. G. Mednik, and V. M. Prokhorov, Soviet Journal of Ecology 7, 195 (1976) (Eng. trans1.).

12. R. M. Aleksakhin, M. A. Naryshkin, and M. A. Bocharova, Dokl. Akad. Nauk SSR 193, 1192 (1970) (In Russian). 
13. N. P. Arkhipov, Ye A. Fedorov, R. M. Aleksakhin, P. F. Bondar, T. L. Kozhevnikova, and V. V. Suslova, Soviet Soil Science 7, 690 (1975) (Eng. trans1.); Y. A. Polyakov, Radioecology and Decontamination of Soils (Atomizdat, Moscow, 1970) (In Russian), pp. 238-268 .

14. Ye. I. Belova and Z. G. Antropova, in Nuclear Meteorology, K. P. Makhon'ko and S. G. Malakhov, eds. (Israel Program for Scientific Translations, Keter Press, Jerusalem, Israel, 1974), pp. 72-75.

15. Ye. I. Belova, A. Ya. Kogotkov, and R. K. Pogodin, Hygiene and Sanitation 35, 298 (1970) (Eng. trans1.).

16. V. M. Bochkarev, Z. G. Antropova, and Ye. I. Belova, Soviet Soil Science 9, 936 (1964) (Eng. trans1.).

17. L. V. Cherezhanova, R. M. Aleksakhin, and E. G. Smirnov, Soviet Genetics 7, 437 (1971) (Eng. trans].).

18. N. P. Dubinin, Uspekhi Sovremennoi Genetiki 4, 170 (1972) (In Russian).

19. M. C. Gilyarov, and D. A. Krivolutskii, Zoologicheskii Zhurnal 50, 329 (1971) (In Russian).

20. A. I. Il'enko, Zoologicheskii Zhurnal 47, 1695 (1968) (In Russian).

21. A. I. Il'enko, Problems of Icthyology 10, 860 (1970) (Eng. trans1.).

22. A. I. I1'enko, Radiobiology 10, 243 (1970) (Eng. trans1.).

23. A. I. Il'enko, Zhurnal Obschei Biologii 31, 698 (1970) (Eng. trans1. by Scientific Translation Service, Ann Arbor, MI, Order No. 13047,1973 ). 
24. A. I. Il'enko, Zoologicheskii Zhurnal 49, 1884 (1970) (In Russian).

25. A. I. Il'enko, Zoologicheskii Zhurnal 50, 243 (1971) (In Russian).

26. A. I. I7'enko, Problems of Icthyology 12, 149 (1972) (Eng. trans1.).

27. A. I. Il'enko and Ye. A. Fedorov, Zoologicheskii Zhurnal 49, 1370 (1970) (In Russian).

28. A. I. Il'enko and A. D. Pokarzhevskii, Zoologicheskii Zhurnal 51, 1219 (1972) (In Russian).

29. A. I. Il'enko and I. A. Ryabtsev, Zoologicheskii Zhurnal 53, 308 (1974) (In Russian).

30. A. I. I7'enko and G. N. Romanov, Radiobiology 7, 117 (1967) (Eng. transi.).

31. A. I. IT'enko, S. I. Isaev, and I. A. Ryabtsev, Radiobiology 14, 126 (1974) (Eng. transi.).

32. A. I. II'enko, I. A. Ryabtsev, and D. E. Fedorov, Zoologicheskii Zhurnal 54, 1678 (1975) (In Russian).

33. S. I. Isaev, Soviet Journal of Ecology 6, 33 (1975) (Eng. transi.).

34. R. T. Karaban and F. A. Tikhomirov, Radiobiology 7, 188 (1967) (Eng. trans1.).

35. V. M. Klechkovskii, G. G. Polikarpov, and R. M. Aleksakhin, Radioecology, (Israel Program for Scientific Translations, John Wiley and Sons, New York, N.Y., 1973). 
36. N. A. Korneev, S. K. Firsakova, V. A. Gromov, A. V. Ivanova, A. Ya. Kogotkov, N. V. Korneeva, Ye. M. Nikolaeva, S. S. Shain, and I. G. Tepiyakov, in The Radiobiology and Radioecology of Farm Animals, B. N. Annenkov, I. K. Dibobes, and R. M. Aleksakhin, Eds. (AEC-tr-7523, N.T.I.S., U.S. Dept. of Commerce, Springfield, Virginia, 1974) (Eng. transt.), pp. 8-24.

37. Yu. D. Korsakov, I. Ya. Poplyko, and I. A. Ternovskii, in Handling of Radiation Accidents, (IAEA, Vienna, 1969) (In Russian), pp. 281-285.

38. D. A. Krivolutskii, and A. D. Pokarzhevskii, Zhurnal Obschei Biologii 35, 263 (1974) (In Russian).

39. D. A. Krivolutskii, A. L. Tikhomirova, and V. A. Turchaninova, Pedobiologia 12, 374 (1972) (Eng. trans1., ORNL-tr-2823).

40. V. V. Pisarev, I. A. Koloskov, V. M. Kuznetsova, and I. S. Tsybizov, Soviet Soil Science 4, 193 (1972) (Eng. trans1.).

41. G. B. Pitkyanen and N.G. Safronova, Radioecology of Water Organisms, Vol. 2 ("Zinatne" Publishing House, Riga, Latvia, U.S.S.R., 1973) (In Russian), pp. 140-146.

42. V. M. Prokhorov, Soviet Radiochemistry 11, 310 (1969) (Eng. trans1.).

43. V. M. Prokhorov and N. G. Safronova, Soviet Journal of Ecology 4 , 101 (1973) (Eng. trans1.).

44. V. M. Prokhorov, M. V. Ryzhinsky, R. M. Aleksakhin, and V. F. Gol'tsev, Soviet Soil Science 1, 47 (1974) (Eng. trans1.). 45. F. Ya. Rovinskii, Atomic Energy 18, 480 (1965) (Eng. trans1.). 46. F. Ya. Rovinskii, Soviet Radiochemistry 9, 76 (1967) (Eng. trans1.). 
47. F. Ya. Rovinskii and A. L. Agre, Hygiene and Sanitation 31, 337 (1966) (Eng. trans1.).

48. G. A. Sereda and F. Ya. Rovinskii, Atomic Energy 14, 327 (1962) (Eng. trans1.).

49. V. A. Shevchenko, A. Ya. Alekseenok, and D. R. Pyatyshev, Proceedings of the 6th Working Conference on Material Circulation in Closed Systems (Naukova Dumka, Kiev, 1969), P. 62; V. A. Shevchenko, Soviet Genetics 6, 1042 (1970) (Eng. transi.).

50. E. G. Smirnov and F. A. Tikhomirov, Soviet Journal of Ecology 6 , 102 (1975) (Eng. trans1.).

51. V. Ye. Sokolov and A.I. Il'enko, Uspekhi souremennoi biologii 67, 235 (1969) (In Russian).

52. F. A. Tikhomirov, R. M. Aleksakhin, and Ye. A. Fedorov, in Proceedings of the Fourth International Conference on the Peaceful Uses of Atomic Energy, V. 11 (United Nations, Geneva and IAEA, Vienna, 1972), pp. 675-688.

53. A. D. Pokarzhevskii and S. I. Isaev, Soviet Journal of Ecology 8, 324 (1977) (Eng. trans1.).

54. D. A. Krivolutskii, L. P. Marakushina, and A. V. Smurov, Soviet Journal of Ecology 8, 134 (1977) (Eng. trans1.).

55. A. I. Il'enko, R. B. Mazheikite, G. V. Nizhnik, and I. A. Ryabtsev, Radiobiologiya 17, 545 (1977) (In Russian).

56. S. V. Iokhel'son and D. K. Popov, Atomic Energy 16, 180 (1964) (Eng. transi.).

57. N. V. Kulikov, M. Ya. Chebotina, and V. F. Bochenin, Soviet Journal of Ecology 8, 34 (1977) (Eng. trans1.). 
58. L. I. Piskunov and B. V. Popov, Soviet Journal of Ecology 5, 276 (1974) (Eng. trans1.).

59. V. P. Shvedov and S. I. Shirokov, Eds., Radioactive Contamination of the External Environment (AEC-tr-6049, N.T.I.S., U.S. Dept. of Commerce, Springfield, Virginia, 1962) (Eng. trans1.).

60. N. A. Timofeeva and N. V. KuTikov, in Radioecological Concentration Processes, B. Aberg and F. P. Hungate, Eds., (Pergamon Press, New York, New York, 1967) (Eng. trans1.), pp. $835-841$.

61. R. L. Moore and R. E. Burns, in Proceedings of the Second United Nations International Conference on the Peaceful Uses of Atomic Energy, V. 18 (United Nations, Geneva, 1958), pp. 231-236.

62. A. F. Rupp, in Proceedings of the International Conference on the Peaceful Uses of Atomic Energy, V. 14 (United Nations, New York, 1956), pp. 68-84.

63. A. L. Agre and M. M. Telitschenko, Moskovskoe Obshchestvo Ispytatelei Prirody Byulleten. Otdel Biologicheskii 68, 133 (1963) (In Russian).

64. A. L. Agre, I. V. Molchanova, and S. N. Chekalova, Moskovskoe Obschestvo Ispytatelei Prirody Byulleten. Otdel Biologicheskii 71, 124 (1966) (In Russian).

65. N. V. Kulikov, Soviet Soil Science (6), 678 (1965) (Eng. trans1.).

66. N. V. Kulikov, I. V. Molchanova, and E. N. Karavaeva, Soviet Journal of Ecology 4, 320 (1973) (Eng. trans1.).

67. I. V. Molchanova, E. N. Karavaeva, and N. V. KuTikov, Soviet Journal of Ecology 3, 257 (1972) (Eng. trans7.). 
68. A. A. Titiyanova and N. A. Timofeyeva, Soviet Soil Science 3,346 (1959) (Eng. trans1.).

69. N. E. Brezhneva, V. I. Levin, G. V. Korpusov, and N. M. Manko, and E. K. Bogachova, in Proceedings of the Second United Nations International Conference on the Peaceful Uses of Atomic Energy, V. 18 (United Nations, Geneva, 1958) (Eng. trans1.), pp. 219-230.

70. F. R. Bruce, in Disposal of Radioactive Wastes, V. 1, (IAEA, Vienna, 1960), pp. 3-50.

71. F. R. Bruce, J. M. Fletcher, H. H. Hyman, and J. J. Katz, Eds., Progress in Nuclear Energy. III. Process Chemistry. (Pergamon Press, New York, New York, 1956).

72. E. A. Coppinger and R. E. Tomlinson, Chemical Engineering Progress 52, 417, (1956).

73. P. F. Dolgikh, L. A. Vladimirov, and F. P. Yudin, Atomic Energy 29, 1140 (1970) (Eng. trans1.).

74. E. Glueckauf, Ed., Atomic Energy Waste (Interscience Publishers Inc., New York, New York, 1961).

75. A. T. Gresky, Nuclear Fuel Cycle Research in Russia: A Literature Survey, (ORNL-CF-63-12-46, Rev. 1, Oak Ridge National Laboratory, Oak Ridge, TN, May 1964).

76. E. D. Mal'tsev, F. P. Yudin, V. S. Shamin, and P. F. Dolgikh, Atomic Energy 12, 36 (1962) (Eng. trans1.).

77. A. M. Petrosyants, From Scientific Search to Atomic Industry, (The Interstate Printers and Publishers, Inc., Danville, Illinois, 1975) (Eng. trans1.).

78. W. A. Rodger, in Disposal of Radioactive Wastes, V. 1, (IAEA, Vienna, 1969) pp. 449-482. 
79. V. B. Shevchenko, N. S. Povitsky, and A. S. Solovkin, in Proceedings of the Second United Nations International Conference on the Peaceful Uses of Atomic Energy, V. 17 (United Nations, Geneva, 1958) (Eng. trans1.), pp. 46-48.

80. J. I. Stevens, in Disposal of Radioactive Wastes, V. 1, (IAEA, Vienna, 1960) pp. 483-508.

81. V. M. Vdovenko, Proceedings of the Second United Nations International Conference on the Peaceful Uses of Atomic Energy, V. 17, (United Nations, Geneva, 1958) (Eng. trans1.), pp. 175-179.

82. V. M. Vdovenko and M. P. Kovalskaya, in Proceedings of the Second United Nations International Conference on the Peaceful Uses of Atomic Energy, V. 17, (United Nations, Geneva, 1958) (Eng. trans 1.), pp. 329-332.

83. V. S. Yemel'yanov and A. I. Yevstyukhin, Metallurgy of Atomic Energy, (Atomizdat, Moscow, 1964) (In Russian).

84. F. P. Yudin, M. K. Pimenov, A. I. Nazarov, S. I. Zakharov, S. V. Metal'nikov, and V. M. Sedov, Atomic Energy 25, 886 (1968) (Eng. trans 1.).

85. P. V. Zimakov and V. V. Kulichenko, in Disposal of Radioactive Wastes, V. 1, (IAEA, Vienna, 1960) (Eng. trans].), pp. 441-448.

86. F. A. Tikhomirov, Soviet Journal of Ecology 4, 380 (1973) (Eng. trans.).

87. R. M. Aleksakhin, F. A. Tikhomirov, and N. V. Kulikov, Soviet Journal of Ecology 1, 19 (1970) (Eng. trans1.).

88. Reference 35, pp. 146-148. 
89. A. N. Marei, and M. M. Saurov, Preprint SM-72/33 from Symposium for the Disposal of Radioactive Wastes into Seas, Oceans, and Surface Waters (IAEA, Vienna, 1966) (In Russian).

90. A. N. Marei, G. I. Gneusheva, O. A. Balandin, E. G. Repina, and G. A. Kuznetsova, Gigiena i Sanitariya 41, 57 (1976) (In Russian).

91. G. B. Pitkyanen, and Yu. A. Zaitsev, Soviet Journal of Ecology 5 , 566 (1974) (Eng. trans 1.).

92. D. I. I ' in, and Yu. I. Moskalev, in Distribution, Biological Effects, and Migration of Radioactive Isotopes, A. V. Lebedinskii and Yu. I. Moskalev, Eds., (AEC-tr-7512, N.T.I.S., U.S. Dept. of Commerce, Springfield, Virginia, 1974) (Eng. trans1.), pp. $379-408$.

93. D. I. I1'in, Yu. I. Moskalev, and A. I. Petrova, Atomic Energy 5, 1013 (1958) (Eng. trans?.).

94. Z. M. Balabanova, Izv. VNII Ozernovo i Rechnovo Rybnovo Khozyaistva 39, 93 (1957).

95. Rossiiskaya Federatsiya, Ural, (Komar I. V., Moscow, 1969) (In Russian).

96. J. R. Ellerman, The Families and Genera of Living Rodents, (Stechert-Hafner, Inc., New York, New York, 1966).

97. V. P. Tseplyaev, The Forests of the U.S.S.R. (Israel Program for Scientific Translations, Daniel Davey and Co., Inc., New York, N.Y., 1974).

98. K. P. Gorshenin, The Soils of Southern Siberia, (Israel Program for Scientific Transiations, Office of Technical Services, U.S. Dept. of Commerce, Washington, D.C., 1961) (Eng. trans1.). 
99. Soils of the U.S.S.R., Part I-II, (Israel Program for Scientific Translations, Jerusalem, Israe1, 1962) (Eng. trans1.).

100. Yu. A. Israel and E. N. Teverovskii, Atomic Energy 31, 1177 (1971).

101. United Nations Scientific Committee on the Effects of Atomic Radiation, Ionizing Radiation, Levels and Effects, Vol. 1, Levels (United Nations, New York, 1972).

102. F. Ya. Rovinskii, G. K. Morozova, E. D. Sinitsina, and N. M. Sinitsin, in Radioecology of Water Organisms, V. 2, ("Zinatne" Publishing House, Riga, Latvia, U.S.S.R., 1973) (In Russian), pp. $20-29$.

103. R. T. Karaban, and F. A. Tikhomirov, Lesovedenie (2), 91 (1968) (In Russian); D. A. Krivolutskii and T. L. Kozhevnikova, Soviet Journal of Ecology 3, 148 (1972) (Eng. trans 1.); V. A. Turchaninova and F. A. Tikhomirov, Soviet Journal of Ecology 4, 453 (1973) (Eng. trans7.).

104. B. S. Prister, T. A. Grigor'yeva, V. M. Pereventsev, F. A. Tikhomirov, V. G. Sal'nikov, I. M. Ternovskaya, and R. T. Karaban, Soviet Soil Science (6), 316 (1977) (Eng. trans1.). 105. D. A. Krivolutskii, and M. N. Fedorova, Zoologicheskii Zhurnal 52, 601 (1973) (ORNL-tr-2824, Oak Ridge National Laboratory, Oak Ridge, Tennessee 37830).

106. Times Newspapers, Ltd. Times Atlas of the Wor Id, Comprehensive Edition, (Times Newspapers, Ltd. and Bartholomew, John and Sons, Ltd., London 1972). 
107. A. F. Karpevich and Ye. N. Bokova, Voprosy Ikhtiologi 1 1, 552 (1961), 3,366 (1963): A. F. Karpevich and I. Ye. Lokshina, Voprosy Ikhtiologii 5, 178 (1965), ㅁ, 698 (1965), ㄱ, 1105 (1967);

A. F. Karpevich and N. K. Lukonina, Voprosy Iktiologii 8, 1063 (1968) (In Russian); A. F. Karpevich and N. K. Lukonina, Problems of Icthyology 10, 404 (1970), 11, 98 (1971), 12, 325 (1972) (Eng. trans 1.).

108. P. A. Dryagin, in Acclimatization of Animals in the U.S.S.R. (Israel Program for Scientific Translations, Jerusalem, Israel, 1966) (Eng. trans1.), pp. 4-5.

109. G. A. Modelski, Atomic Energy in the Communist Bloc (Cambridge University Press, New York, 1959).

110. R. E. Tomlinson, editor, Radioactive Wastes from the Nuclear Fuel Cycle, AIChE Symposium Series, Number 154, Volume 72, (American Institute of Chemical Engineers, New York, 1976).

111. 0. F. Hi17, and V. R. Cooper, Ind. Eng. Chem. 50, 599 (1958); S. Lawroski, Chem。 Eng. Prog. 51, 461 (1955).

112. D. I. Semenov, in Metabolism of Radioisotopes in the Animal Organism (AEC-tr-7169, N.T.I.S., U.S. Dept. of Commerce, Springfield, Virginia, 1970) (Eng. transi. of Tr. Inst. Biol. Adad. Nauk SSSR, Ural. Filial, No. 46, 1-158, 1966), pp. 15-32.

113. R. E. Connick, J. W. Gofman, and A. C. Wahl, in Manhattan Project Report for November 16-31, 1942, CN-363 (1942), pp. 1-10; R. E. Connick, R. B. Duffield, C. S. Garner, J. W. Gofman, and A. C. Waht, in Manhattan Project Report for Period Ending February 13, 1943, CN-467 (1943), pp. 15-19. 
114. W. G. Belter, in Proceedings of the Third International Conference on the Peaceful Uses of Atomic Energy, V. 14 (United Nations, New York, 1965), pp. 302-312; 0. H. Pilkey, A. M. Platt, and C. A. Rohrman, in Proceedings of the Second United Nations International Conference on the Peaceful Uses of Atomic Energy, V. 18 (United Nations, Geneva, 1958), pp.7-18; E. E. Wilson, in Reactor Operational Problems, V. II (Pergamon Press, New York, 1957), pp. 29-35.

115. Disposal in the Ground, Session 23 B.1, in Proceedings of the International Conference on the Peaceful Uses of Atomic Energy, V. 9 (United Nations, New York, 1956), pp. 669-700; Record of Session, C-21, in Proceedings of the Second International Conference on the Peaceful Uses of Atomic Energy, V. 18 (United Nations, Geneva, 1958), pp. 118-119.

116. A. V. Topchiev, I. T. Aladiev, and P. S. Savitsky, in Proceedings of the Second United Nations International Conference on the Peaceful Uses of Atomic Energy, V. 19, (United Nations, Geneva, 1958) (Eng. trans1.), pp. 61-75.

117. E. Lamb, H. E. Seagren, and E. E. Beauchamp, in Proceedings of the Second United Nations International Conference on the Peaceful Uses of Atomic Energy, V. 20 (United Nations, Geneva, 1958), pp. 38-44.

118. L. P. Rogers, in Disposal of Radioactive Wastes, V. 1 (IAEA, Vienna, 1960), pp. 53-61. 
119. 0. L. Kedrovskii, in Translations of French and Soviet Papers Presented at Second Panel on the Peaceful Uses of Nuclear Explosions, Vienna, Austria, 18-22 January, 1971, (UCRL-trans-10543, N.T.I.S., U.S. Dept. of Commerce, Springfield, Virginia, 1971) (Eng. trans1.); I. D. Morokhov, Ed., Nuclear Explosions for Peaceful Purposes, (UCRL-trans-10517, N.T.I.S., U.S. Dept. of Commerce, Springfield, Virginia, 1971) (Eng. trans 1.): B. I. Nifontov, D. D. Protopopov, I. E. Sitnikov, and A. V. Kulikov, Underground Nuclear Explosions (Atomizdat, Moscow, 1965) (In Russian); A. R. W. Wi Tson, in Proceedings of the Fourth International Conference on the Peaceful Uses of Atomic Energy, V. 7 (United Nations, Geneva and IAEA, Vienna, 1972), pp. 211-231.

120. A. N. Marei, in Distribution, Biological Effects, and Migration of Radioactive Isotopes, A. V. Lebedinskii and Yu. I. Moskalev, Eds., (AEC-tr-7512, N.T.I.S., U.S. Dept. of Commerce, Springfield, Virginia, 1974) (Eng, trans1.), pp. 349-358, 388-408.

121. S. Glasstone, and P. J. Dolan, eds., The Effects of Nuclear Weapons (U.S. Departments of Defense, and Energy, 1977).

122. R. Bjornerstedt, Arkiv Fis. 16, 293 (1959).

123. Radioactivity of Fission Products Important in Processing, Appendix III in reference 71.

124. S. J. Rimshaw, Fission Product Calculations, Oak Ridge National Laboratory, Oak Ridge, Tennessee, unpublished material, February $24,1958$. 
125. Radiological Health Handbook (PB 121 784R, Public Health Service, Division of Radiological Health, U.S. Dept. of Health, Education, and Welfare, Washington, 25 D.C., September 1960).

126. E. E. Motta, in Proceedings of the International Conference on the Peaceful Uses of Atomic Energy, v. 9 (United Nations, New York, 1956), pp. 596-603.

127. H. J. Dunster, H. Howe 11s, and W. L. Templeton, in Proceedings of the Second United Nations International Conference on the Peaceful Uses of Atomic Energy, V. 18 (United Nations, Geneva, 1958), pp. 296-308.

128. V. M. Prokhorov, Soviet Soil Science (11), 724 (1975) (Eng. trans 1.): H. M. Squire and L. J. Middleton, Radiation Botany 6, $413(1966)$.

129. I. J. Gal, and A. Ruvarac, Bull. Inst. Nucl. Sci. "Boris Kidrich" (Belgrade) 13, 1 (1962); I. Gal, and A. Ruvarac, J. Chromatog. 13,549 (1964).

130. Symposium on the Reprocessing of Irradiated Fuels Held at Brussels, Belgium, May 20-25, 1957, Book 1 (TID-7534, Technical Information Service Extension, Oak Ridge, Tennessee, 1957); R. G. Wymer, personal communication, November 29, 1978. 
131. M. I. Goldman, J. A. Servizi, R. S. Daniels, T. H. Y. Tebbutt, R. $T$. Burns, and R. A. Lauderdale, in Proceedings of the Second United Nations International Conference on the Peaceful Uses of Atomic Energy, V. 18 (United Nations, Geneva, 1958), pp. 27-32;

J. W. Loeding, A. A. Jonke, W. A. Rodger, R. P. Larsen, S. Lawroski, E. S. Grimmett, J. I. Stevens, and C. E. Stevenson, in Proceedings of the Second United Nations International Conference on the Peaceful Uses of Atomic Energy, V. 18 (United Nations, Geneva, 1958), pp. 56-67; L. C. Watson, R. W. Durham, W. E. Erlebach, and H. K. Rae, in Proceedings of the Second United Nations International Conference on the Peaceful Uses of Atomic Energy, V. 18 (United Nations, Geneva, 1958), pp. 19-26.

132. J. M. Holmes, personal cormunication on Soviet practice reported at IAEA High Level Waste Disposal Conference, Vienna, October 8-13, 1962, October 10, 1978.

133. Handbook of Chemistry and Physics (Chemical Rubber Co., Cleveland, Ohio, 1966).

134. J. A. McBride, E. B. Sheldon, W. S. Frank, and J. C. Bresee, in Proceedings of the Third International Conference on the Peaceful Uses of Atomic Energy, V. 13 (United Nations, New York, 1965), pp. 194-203; Operational Accidents and Radiation Exposure Experience Within the United States Atomic Energy Commission, 1943-1975 (WASH-1192 Rev., USAEC, Division of Operational Safety, Washington, D.C., 1975); R. Gillette, Science 181, 728, 1973. 
135. J. N. Fairlie and A. J. W. Hitchman, A Report on the Effects of the Chemical Explosion of December 13, 1950 at Chalk River Nuclear Research Laboratories (AECL-1687, Atomic Energy of Canada, Ltd., Chalk River, Ontario, Canada, January 1963).

136. M. A. Cook, The Science of High Explosives, (Reinhold Publishing Corporation, New York, New York, 1958).

137. C. H. Johansson and P. A. Persson, Detonics of High Explosives, (Academic Press, New York, New York, 1970).

138. M. Meyer, The Science of Explosives, (Thomas Y. Crowell Company, New York, New York, 1943).

139. R. M. Hainer, Fifth International Symposium on Combustion (Reinhold Publishing Corporation, New York, 1955), pp. 224-230.

140. E. K. Hyde, in Proceedings of the International Conference on the Peaceful Uses of Atomic Energy, V. 7 (United Nations, New York, 1956), pp. 281-302.

141. V. Spitsyn, in Nuclear Engineering, AIChE Symposium Series, No. 27, Volume 55 (American Institute of Chemical Engineers, New York, 1959), pp.1-31.

142. D. I. Il'in, A. I. Petrova, and N. Ya. Chepkasova, Atomic Energy 5, 890 (1958) (Eng. trans1.); V. I. Spitsyn, Nukleonika 2, 451 (1957); V. I. Spitsyn, V. D. Balukova, A. F. Naumova, V. V. Gromov, F. M. Spiridonov, E. M. Vetrov, and G. I. Grafov, in Proceedings of the Second International Conference on the Peaceful Uses of Atomic Energy, V. 18 (United Nations, Geneva, 1958), pp. 439-448. 
143. B. M. Agafonov, Trudy Vsesoyuz. Conf. Med. Radiol., Voprosy Gigieny i Dozimetrii, 26 (1956), 79 (1957), 63 (1958) (In Russian): A. L. Agre and V. I. Kogorodin, Medical Radiology 5 , 161 (1960) (Eng. trans1.): A. L. Agre, Moskovskoe Obshchestvo Ispytatelei Prirody Byulleten. Otdel Biologicheskii 67, 45 (1962): A. L. Agre, A. P. Raiko, and N. V. Timofeev-Resovsky, Moskovskoe Obshchestvo Ispytatelei Prirody Byulleten. Otdel Biologicheskii 67, 120 (1962); Reference 63; A. L. Agre, I. V. Molchanova, and N. V. Timofeev-Resovsky, Moskovskoe Obshchestvo Ispytatelei Prirody Byulleten. Otdel Biologichesk i1 69, 20 (1964): Reference 64; E. A. Timofeeva-Resovskaya, Trudy Vsesoyuz. Conf. Med. Radiol., Voprosy Gigieny i Dozimetrii, 83 (1957): E. A. Timofeeva-Resovskaya, Moskovskoe Obshchestvo Ispytatelei Prirody Byulleten. Otdel Biologicheskif 62, 37 (1957) (In Russian).

144. A. I. Burnazyan, S. M. Gorodinskii, L. A. Il'in, V. M. Kozlov, A. N. Marei, G. M. Parkhomenko, and A. D. Turkin, Atomic Energy 31, 1158 (1971) (Eng. trans1.); V. I. Spitsyn, M. K. Pimenov, V. D. Balukova, A. S. Leontychuk, I. N. Kokorin, F. P. Yudin, and N. A. Rakov, in International Conference on Nuclear Power and Its Fuel Cycle (IAEA, Vienna, 1977) (In Russian), pp. 481-502.

145. First citation in Ref. 130. 
146. V. I. Spitsyn, B. S. Kolychov, and V. M. Sedov, in Treatment and Disposal of Radioactive Wastes - U.S.S.R., JPRS 51948 (Joint Publications Research Service, U.S. Dept. of Commerce, NTIS, Springfield, Virginia, 8 Dec, 1970), (Eng. trans1.), pp. 1-32; V. V. Kulichenko, O. I. Volkova, K. P. Zakharova, I. S. Sobolev, L. M. Khomchik, V. V. Dolgov, G. D. Kosenko, and V. I. Davydov, ibid, pp. 68-84.

147. Operation Castle - Final Report Project 4.1, Study of Response of Human Beings Accidentally Exposed to Significant Fallout Radiation, WT-923 (AEC Technical Information Service, P.O. Box 401, Oak Ridge, Tennessee, 1954). 
-$$
\text { . }
$$ 
INTERNAL DISTRIBUTION

1. H. S. Arora

2-51. S. I. Auerbach

52. J. A. Auxier

53. T. M. Besmann

54. R. E. B 7 anco

55. B. G. B T aylock

56. J. 0. Blomeke

57. W. J. Boegly

58. E. A. Bondietti

59. R. L. Burgess

60. C. V. Chester

61. C. C. Coutant

62. R. B. Craig

63. N. H. Cutshal1

64. J. W. Elwood

65. R. J. Floran

66. W. Fulkerson

67. C. T. Garten

68. A. T. Gresky

69. W. F. Harris

70. S. G. Hildebrand

71. J. M. Holmes

72. S. V. Kaye

73. A. D. Kelmers

74. R. K. Kibbe

75. I. L. Larsen

76. S. Y. Lee

77. R. S. Livingston

78. J. M. Loar

79. A. L. Lotts
80. R. S. Lowrie

81. F. R. Mynatt

82. L. T. Newman

83. J. S. 01 son

84. H. A. Pfuderer

85. D. E. Reichle

86. C. R. Richmond

87. S. J. Rimshaw

88. P. S. Rohwer

89. R. D. Roop

90. A. T. Szluha

91. T. Tamura

92-141. J.R. Trabalka

142. D. B. Trauger

143. R. I. Van Hook

144. W. Van Winkle

145. D. A. Webster

146. J. P. Witherspoon

147. R. G. Wymer

148. G. T. Yeh

149. Energy Technology Library

150. ESD Library

151. Biology Library

152-153. Central Research Library

154. Civil Defense Library

155-156. Laboratory Records Dept.

157. Laboratory Records, ORNL-RC

158. ORNL Y-12 Technical Library

159. ORNL Patent office

\section{EXTERNAL DISTRIBUTION}

160. P. H. Abelson, Editor, Science, 1515 Massachusetts Ave., NW, Washington, DC 20005

161. F. Anderson, Swedish Natura 1 Research Counci?, Wenner-Gren Building, Stockholm, Sweden

162. Nathaniel F. Barr, Divis ion of Technology Overview, Department of Energy, Washington, DC 20545

163. Harold Berkson, U.S. Nuclear Regulatory Commission, Washington, DC 20555

164. Charles W. Billups, Environmental Specialists Branch, Division of Site Safety and Environmental Analysis, U.S. Nuclear Regulatory Commission, Washington, DC 20555

165. Philippe Bourdeau, Biologist, Environmental Affairs, EURATOM, Brussels, Belgium 
166. R. W. Brocksen, Electric Power Research Institute, 3412 Hillview Ave., P.0. Box 10412, Palo Alto, CA 94304

167. J. D. Buffington, Council on Environmental Quality, 722 Jackson Place, NW, Washington, DC 20006

168. Harry T. Burn, Technical Librarian, ORAU/MERT, Oak Ridge, TN 37830

169. W. W. Burr, Office of Health and Environmental Research, Department of Energy, Washington, DC 20545

170. J. Thomas Callahan, Associate Director, Ecosystems Studies Program, National Science Foundation, Washington, DC 20550

171. P. M. Cate, International Atomic Energy Agency, P.0. Box 590, Karntner Ring 11, A-1011, Vienna, Austria

172. Ruth C. Clusen, Assistant Secretary for Environment, Department of Energy, Washington, DC 20585

173. W. J. Coppoc, Texaco, Inc., P. O. Box 509, Beacon, NY 12508

174. William Crowe, Fuel Processing and Fabrication Branch, U.S. Nuclear Regulatory Commission, 7915 Eastern Avenue, Silver Springs, MD 20906

175. F.L. Culler, Electric Power Research Institute, Palo Alto, CA 94304

176. C. E. Cushing, Ecosystems Department, Battelle-Northwest Laboratories, Richland, WA 99352

177. R. C. Dahlman, Office of Health and Environmental Research, Department of Energy, Washington, DC 20545

178. G. H. Daly, Waste Management Division, Department of Energy, Washington, DC 20545

179. J. J. Davis, Division of Safeguards, Fuel Cycle, and Environmental Resarch, U.S. Nuclear Regulatory Commission, Washington, DC 20555

180. Stanley N. Davis, Head, Department of Hydrology and Water Resources, University of Arizona, Tucson, AZ 85721

181. George Debucanane, Radiohydrology Branch, U. S. Department of the Interior, U.S. Geological Survey, Reston, VA 22070

182. Harold R. Denton, Division of Site Safety and Environmental Analysis, U.S. Nuclear Regulatory Commission, Washington, DC 20555

183-184. John Deutsch, Deputy Secretary of Energy, Department of Energy, Washington, DC 20545

185. Director, Environmental Assessment Department, Electric Power Research Institute, Palo Alto, CA 94304

186. Division of Defense Intelligence, office of International Security Affairs, Department of Energy, Washington, DC 20585

187. David Dixon, 34 Elm Grove, Swainswick, Bath, BA1 7BA, Avon, UK

188. G. W. Dolphin, National Radiological Protection Board, B1dg. 566, Harwe 11, Didcot, Oxfordshire 0X11 ORQ England

189. L.P. Duffy, EG\&G Idaho, Inc., P. 0. Box Fal1s, ID 83401

190. Pau 7 B. Dunaway, Office of Effect Evaluation, Department of Energy, Nevada Operations Office, P.0. Box 1400, Las Vegas, NV 89114

191. P. Duvigneaud, Director, Laboratoire de Botanique Systematique et d'Ecologie, Universite Libre de Bruxelles, 28 Avenue Paul Heger, Bruxelles 5, Belgium 
192. Mel E. Dyer, Program Director, Ecosystem Studies Program, National Science Foundation, Washington, DC 20550

193. Charles W. Edington, Office of Health and Environmental Research, Department of Energy, Washington, DC 20545

194. H. C. Eichhorn, Chief, Biology Branch, Water Quality Engineering Division, U. S. Army Environmental Hygiene Agency, Aberdeen Proving Ground, MD 21010

195. Merril Eisenbud, Institute of Environmental Medicine, New York University Medical Center, 550 First Avenue, Room 559, New York, NY 10016

196. Carl D. Eklund, Tennessee Valley Authority, Division of Water Control Planning, 345 Edney Building, Knoxville, TN 37902

197. Robert P. Epple, Division of Materials Science, Department of Energy, ER-152, MS-J309, GTN, Washington, DC 20545

198-247. L. D. Eyman, 5 Longview Kno 11, Iowa City, IA 52240

248. G. C. Facer, Industrial Safety, Environment and Facilities Branch, Division of Military Application, Department of Energy, Washington, DC 20585

249. L. Farges, Project officer of the Coordinated Research Programme, Division of Nuclear Safety and Environmental Protection, International Atomic Energy Agency, Karntner Ring 11, P.0. Box 590 A-1011, Vienna, Austria

250. Ralph Franklin, Office of Health and Environmental Research, Department of Energy, Washington, DC 20545

251. David Friedman, Hazardous Waste Management Division (WH-565), Office of Solid Waste, U.S. Environmental Protection Agency, 401 M Street, S.W., Washington, DC 20460

252. S. J. Gage, Office of Research and Development, Environmental Protection Agency, $401 \mathrm{M}$ Street, NW, Washington, DC 20460

253. Al Galli, U.S. Environmental Protection Agency, Washington, DC 20460

254. Robert M. Garrels, Department of Geological Science, Northwestern University, Evanston, IL 60201

255. Frank A. Gifford, National Oceanic and Atmospheric Administration, Atmospheric Turbulence and Diffusion Laboratory, Oak Ridge, TN 37830

256. Norman R. Glass, National Ecological Research Laboratory, U.S. Environmental Protection Agency, 200 Southwest 35 th Street, Corvallis, OR 97330

257. P.F. Gustafson, Radiological Physics Division, D-203, Argonne National Laboratory, 9700 S. Cass Avenue, Argonne, IL 60439

258. Clinton W. Ha11, U.S. Environmental Protection Agency, Washington, DC 20460

259. D. Heyward Hamilton, Office of Health and Environmental Research, Department of Energy, Washington, DC 20545

260. Allen L. Hammond, Consulting Editor, American Association for the Advancement of Science, 1515 Massachusetts Ave., NW, Washington, DC 2005

261. C. A. Heath, Waste Management Division, Department of Energy, Washington, DC 20545

262. Sir John M. Hi11, Chairman, United Kingdom Atomic Energy Author ity, London, England 
263. H. Hollister, Secretary for Environment, Department of Energy, Washington, DC 20545

264. Peter House, Office of Technology Impacts, Department of Energy, Washington, DC 20545

265. J.W. Huckabee, Electric Power Research Institute, 3412 Hillview Ave., P.0. Box 10412, Palo Alto, CA 94304

266. 0. Ilari, Divisione Protezione Sanitaria E Contpolii, CNEN, Biole Regina Margherita 125, 00198 Roma, Italy

267. E. Iranzo, Jefe de Proteccion y Medicina, Ministerio de Industria, Junta de Energia Nuclear, Avenida Compultense, Madrid 3, Spain

268. Philip L. Johnson, Oak Ridge Associated Universities, Oak Ridge, TN 37830

269. P. R. Kamath, Bhabha Atomic Research Centre, Environmental Studies Section, Health Physics Division, Bombay 85, India

270. N. R. Kevern, Division of Fisheries and Wildlife, Michigan State University, East Lansing, MI 48823

271. Donald King, Man and the Biosphere Program, U.S. Department of State, Washington, DC 20520

272. Jerry R. Kiine, Division of Site Safety and Environmental Analysis, U.S. Nuclear Regulatory Commission, Washington, DC 20555

273. Harry Kornberg, Environmental Assessment Department, Electric Power Resarch Institute, Palo Alto, CA 93404

274. Arnold Kramish, R\&D Associated, 1404 Wi lson BIvd., Suite 500, Arlington, VA 22209

275. T. E. Langford, Central Electricity Research Laboratories, Freshwater Biology Unit, c/o Scientific Services Centre, Ratcliffe-on-Soar, Nottingham, NG 11 OEE, United Kingdom

276. George H. Lauff, W. K. Kellogg Biological Station, Michigan State University, Hickory Corners, MI 49060

277. Simon A. Levin, Ecology and Systematics Department, Cornel1 University, Ithaca, NY 14850

278. Library, Bureau of Sport Fisheries and Wildlife, U.S. Department of the Interior, Washington, DC 20240

279. Library, Food and Agriculture, Organization of the United Nations, Fishery Resources and Environment Division, via delle Termi di Caracalla 00100, Rome, Italy

280. Library, Great Lakes Fishery Laboratory, U.S. Bureau of Sport Fisheries and Wild life, Ann Arbor, MI 49904

281. Library, Western Fish Toxicology Laboratory, Environmental Protection Agency, Corvallis, OR 97330

282. Gene E. Likens, Department of Ecology, 221 Langmuir Laboratory, Cornel1 University, Ithaca, NY 14850

283. 0. R. Lunt, Environmenta 1 Radiation Division, Laboratory of Nuclear Medicine and Radiation, University of California, 900 Veteran Avenue, Los Angeles, CA 90024

284. Michael C. MacCracken, MAP3S Project Director, Lawrence Livermore Laboratory, P. 0. Box 808, Livermore, CA 94550

285. John J. Magnuson, Laboratory of Limnology, The University of Wisconsin, Madison, WI 53706 
286. C. R. Malone, National Academy of Sciences, 2101 Constitution Ave., NW, Washington, OC 20418

287. Jack S. Marsha 11, Radiological Physics Division, Argonne National Laboratory, 9700 S. Cass Avenue, Argonne, IL 60439

288. Massachusetts Institute of Technology, School of Chemical Engineering Practice, Building 1000, P. 0. Box X, Dak Ridge, TN 37830

289. Helen McCammon, Office of Health and Environmental Research, Department of Energy, Washington, DC 20545

290. J. Frank McCormick, Graduate Program in Ecology, University of Tennessee, Knoxville, TN 37916

291. J. S. McMahon, Atomic Energy of Canada Ltd., Biology and Health Physics Division, Chalk River Nuclear Laboratories. Chalk River, Ontario KOJ 1J0, Canada

292. Z. A. Medvedev, Medical Research Counci1, National Institute for Medical Research. The Ridgeway, Mill Hil1, London, England NW7 IAA

293. Don Miller, Environmental Protection Agency, National Marine Water Quality Agency, South Ferry Road, Narragansett, RI 02882

294. Dario M. Monti, Division of Technology Overview, Department of Energy, Washington, DC 20545

295. Voss A. Moore, Assistant Director, Division of Site Safety and Environmental Analysis, U.S. Nuclear Regulatory Commission, Washington, DC 20555

296. John Neuhold, Ecology Center, Utah State University, Logan, UT 84321

297. L. Newman, Director, Atmospheric Sciences Division, Department of Energy and Environment, Brookhaven National Laboratory, Upton, Long Is land, NY 11973

298. Nuclear Fuel Cycle Division, Idaho Operations Office, Department of Energy, 550 2nd St., Idaho Falls, ID 83401

299-301. Nuclear Fuel Cycle and Production Division, Richland Operations Office, Department of Energy, P.0. Box 550, Richland, WA 99352

302. E. P. Odum, University of Georgia, Biology Science, Institute of Ecology, Athens, GA 30601

303. Goetz Derte 1, Waste Management Division, Department of Energy, Washington, DC 20545

304. I. L. Ophel, Biology and Health Physics Division, Atomic Energy of Canada Ltd., Chalk River Nuclear Laboratories, Chalk River, Ontario, Canada

305. W. S. Osburn, Office of Health and Environmental Research, Department of Energy, Washington, DC 20545

306. C. C. Palmiter, Environmental Protection Agency, 5600 Fishers Lane, Rockville, MD 20852

307. F. L. Parker, College of Engineering, Vanderbilt University, Nashville, TN 37235

308. Ruth Patrick, Academy of Natural Sciences, Department of Limnology, Philadelphia, PA 19103 
309. J.W. Pee 1, Department of Energy, Idaho Operations Office, 550 second Street, Idaho Fal1s, ID 83401

310. Alex F. Perge, Waste Management Division, Department of Energy, Washington, DC 20545

311. Raiph Perhac, Electric Power Research Institute, 3412 Hillview Avenue, P. 0. Box 10412, Palo Alto, CA 94304

312. A. Preston, Ministry of Agriculture, Fisheries and Food, Fisheries Radiobiological Laboratory, Hamilton Dock, Lawestoft, Suffolk, England

313. Robert Rabin, National Science Foundation, Washington, DC 20545

314. Gerald J. Rausa, Environmental Protection Agency, 401 M Street, NW, Washington, DC 20460

315. Oscar Ravera, Biology Division, C.C.R., Euratom, 21020 Centro Euratom di Ispra, Ispra, Varese, Italy

316. P.R. Reed, Office of Nuclear Regulatory Research, U.S. Nuclear Regulatory Commission, Washington, DC 20555

317. William H. Regan, Jr., Division of Site Safety and Environmental Analysis, U.S. Nuclear Regulatory Commission, Washington, DC 20555

318. H. A. Regier, Institute for Environmental Studies, University of Toronto, Toronto, Canada

319. Leland C. Rouse, Fuel Processing and Fabrication, U.S. Nuclear Regulatory Commission, 7915 Eastern Avenue, Silver Springs, MD 20906

320. Ross A. Scarano, Fuel Processing and Fabrication Branch, U.S. Nuclear Regulatory Commission, 7915 Eastern Avenue, Silver Springs, MD 20906

321. W. Schikarski, Kernforschungszentrum Karlsruhe, Institute fur Angewante, Systemtechnik und Reaktorphysik, Postfach 3640 , 75 Karlsruhe, Federal Repub Tic of Germany

322. M. J. Schneider, Battelle-Pacific Northwest Laboratories, Battelle Boulevard, Richland, WA 99352

323. G. B. Schofield, Chief Medical Officer, British Nuclear Fuels, Ltd. Windscale \& Calder Works, Sellafield, Seascale, Cumbria, England

324. J. Schwibach, Federal Health office, 8042 Neuherberg bei Munchen, Ingolstadter Laudstr. 1, Federal Republic of Germany

325. A. H. Seymour, College of Fisheries, Laboratory of Radiation Ecology, University of Washington, Seattle, WA 98105

326. Roger Shui1, Division of Environmental Impacts, Department of Energy, Washington, DC 20545

327. David STade, Office of Health and Environmental Research, Department of Energy, Washington, DC 20545

328. Michael Smith, Savannah River Ecology Laboratory, E. I. Dupont Company, Aiken, SC 29801

329. James G. Steger, H-5 Group, Waste Management, Los ATamos Scientific Laboratory, Los Alamos, NM 87544

330. E. G. Struxness, 126 Carnegie Dr., Oak Ridge, TN 37830

331. Frank Swanberg, Jr., U.S. Nuclear Regulatory Commission, Washington, DC 20555 
332. Technical and Production Division, Savannah River Operations office, P.0. Box A, Aiken, SC 29801

333. W. L. Templeton, Ecosystems Department, Battelle-Pac ific Northwest Laboratory, Richland, WA 99352

334. The University of Tennessee Center for the Health Sciences Library, 800 Madison Ave., Memph is, TN 38163

335. J. C. A. Thompson, Librarian, Ecological Analysts, Inc, York Building, 8600 LaSalle Road, Towson, MD 21204

336. Burt Vaughan, Battelle-Pac ific Northwest Laboratory, Rich Tand, WA 99352

337. C. Voigtlander, Division of Forestry, Fisheries, and Wildiife Development, Tennessee Valley Authority, Norris, TN 37838

338. H. E. Walburg, Jr., Director, Comparative Animal Research Laboratory, Oak Ridge, TN 37830

339. Richard H. Waring, Department of Forest Science, Oregon State University, Corvallis, OR 97331

340. Robert Watters, Office of Health and Environmental Research, Department of Energy, Washington, DC 20545

341. A. M. Weinberg, Oak Ridge Associated Universities, Oak Ridge, TN 37830

342. F. W. Whicker, Department of Radiology and Radiation Biology, Colorado State University, Ft. Collins, CO 80521

343. J. W. Whitehouse, Central Electricity Research Laboratories, Kelvin Avenue, Leatherhead, Surrey KT22 7SE, England

344. J. Whitsett, Department of Energy, Idaho Operations Office, 550 Second Street, Idaho Falls, ID 83401

345. Richard Wilson, Harvard University, Cambridge, MA 02139

346. C. E. Winters, Washington Representative, Union Carbide Corporation, 1730 Pennsylvania Avenue, Washington, DC 20006

347. Robert W. Wood, Office of Health and Environmental Research, Department of Energy, Washington, DC 20545

348. G. M. Woodwe 11, The Ecosystem Center, Marine Biological Laboratory, Woods Hole, MA 02543

349. Office of Assistant Manager, Energy Research and Development, DOE-ORO

350-584. Given distribution as shown in DOE/TIC-4500 under category UC-11, Environmental Control Technology and Earth Sciences 